\title{
Osmanlı Basınına Göre Osmanlı Devleti’nin İktisadi Sorunları ve Çözüm Önerileri (1831-1876 Dönemi)
}

\author{
Economic Problems and Solution Proposals of Ottoman State According to the \\ Ottoman Press (1831-1876)
}

\author{
Dr. Öğr. Üyesi Kenan DEMİR (iD) 1
}

\begin{abstract}
$\ddot{\mathbf{O z}}$
Osmanlı Devleti'nde basın 1831 senesinde devlet tarafından yayımlanan Takvim-i Vekayi gazetesiyle doğmuştur. Bu gazetenin yayımlanmasıyla ülkede devletin politikalarının kamuoyu tarafından öğrenilmesi imkânı doğmuş ve halk devletin iktisadi politikalarından haberdar olmaya başlamıştır. 1840 senesinde yayımlanan Ceride-i Havadis gazetesinin de sütunlarında en çok değinilen konulardan biri de iktisat olmuştur. Bu gazete ülkede serbest iktisat düşüncesinin yayılmasına çalışmış ve ülkenin ziraat alanında kalkınmasını istemiştir. Osmanlı Devleti'nde 1860'lardan sonra ise muhalif yayım politikası güden gazeteler görülmeye başlamıştır. Tasvir-i Efkar, Muhbir, Hürriyet, Terakki, İbret ve Hadika gibi gazeteler ülkenin iktisadi politikalarını eleştirmiş ve devletin iktisat politikalarına yönelik çözüm önerileri getirmiştir. Mehmet Şerif Efendi, Tercüman-ı Ahval'de kalkınma tartışmalarına katılmış Osmanlı'nın sanayileşmesini savunmuştur. Местиа-i Fünun, Tercüman-ı Ahval ve Mir'at gibi gazeteler de 1863 senesinde açılan Sergii Umumi Osmani’nin açılışını yönelik yazılar yayımlamışlardır. Bu çalışmada Osmanlı Devleti’nde 1831 senesinde ilk gazetenin yayımlanmasından 1876 senesinde Meşrutiyet'in ilan edilmesine kadarki süreçte yayımlanan önemli gazetelerdeki iktisadi yazılar tespit edilmiş ve bu yazılar ışı̆̆ında dönemin iktisadi sorunları ve tartışmaları verilmiştir.
\end{abstract}

Anahtar Kelimeler: Osmanlı Devleti, gazeteler, iktisadi tartışmalar

Makale Türü: Derleme

\begin{abstract}
The Ottoman press was born in 1831 with the newspaper Gazete-i Vekayi, which was published by the state. With the publication of this newspaper, it became possible for the public to learn the policies of the state in the country and the public became aware of the economic policies of the state. Ceride-i Havadis newspaper, published in 1840, was one of the most mentioned topics in the economy. This newspaper tried to spread free economic thought in the country and wanted the country to develop in the field of agriculture. After the 1860s in the Ottoman Empire, newspapers with dissenting policies began to be seen. The newspapers such as Tasvir-i Efkar, Muhbir, Hürriyet, Terakki, İbret and Hadika criticized the economic policies of the country and proposed solutions for the economic policies of the state. Mehmet Şerif Efendi participated in the development debates in Tercüman-1 Ahval and defended the industrialization of the Ottoman Empire. Newspapers such as Mecmua-i Fünun, Tercüman-1 Ahval and Mir'at also published articles about the opening of the Sergi-i Umumi Osmani, which was opened in 1863. In this study, the economic articles of the important newspapers published in the period from the publication of the first newspaper in the Ottoman Empire in 1831 to the proclamation of the Constitutional Monarchy in 1876 were identified and the economic problems and debates of the period were given.
\end{abstract}

Keywords: Ottoman Empire, newspapers, economic discussions

Paper Type: Review

${ }^{1}$ İstanbul Medipol Üniversitesi, İşletme ve Yönetim Bilimleri Fakültesi, kdemir@medipol.edu.tr.

Atıf için (to cite): Demir, K. (2019). Osmanlı Basınına Göre Osmanlı Devleti'nin İktisadi Sorunları ve Çözüm Önerileri (1831-1876 Dönemi). Afyon Kocatepe Üniversitesi Sosyal Bilimler Dergisi, 21(4), 1130-1153. 


\section{Giriş}

Osmanlı Devleti'nde gazetelerin ortaya çıkışı ülkede ikamet eden elçiler ve yabancı şahıslar tarafından çıkarılan gazeteler aracılığıyla gerçekleşmiştir. Yabancı gazetelerin ardı ardına çıkması ve gazetelerin kamuoyu oluşturmada önemli görevler sergilediklerinin anlaşılması sonucu dönemin padişahı II. Mahmud ülkede gazetede çıkartmaya karar vermiş ve bu karar neticesinde ilk Osmanlı gazetesi Takvim-i Vekayi yayımlanmıştır. II. Mahmud'un gazeteyi çıkartmadaki amacı gerçekleştirdiği yenilikleri halka benimsetmek ve halkın bu doğrultuda bilgi sahibi olmasını sağlamak ve yönlendirmekti. Bu arada dış kamuoyunda da Osmanlı Devleti'nin çıarlarını korumak ve Avrupa devletlerine ülkeyi tanıtmak amacıyla Fransızca Le Moniteur Ottoman çıkarılmıştır. Bu iki gazetenin devletin resmi gazetesi olması nedeniyle gazetelerdeki yazılardan devletin politikaları anlaşlabilmektedir. Gazetede değinilen konulardan biri de ekonomi olmuştur. Ekonomi haberlerinde ülke ticaretinin canlı olduğu ve Tanzimat'ın ilanından sonra bir canlanmanın yaşandığı belirtilmiştir. Ayrıca halkın ekonomi bilgisi artırılmaya çalışılmış ve ülkede ticareti engelleyici kısıtlamaların olmadığı vurgulanmıştır.

Osmanlı Devleti'nde ekonomik yazıların fazlaca görüldüğü ve gazetede iktisadi tartışmaların yaşandığ önemli bir yayın organı ülkenin ikinci gazetesi olan ve 1840 senesinde İngiliz tüccar Churchill yönetimde yayımlanan Ceride-i Havadis'tir. Ceride-i Havadis ülkenin ekonomi politikalarının serbest iktisat düşüncesi doğrultusunda şekillendirmek için birçok yazı yayınlamış ve ülke kalkınması için en uygun sektörün ziraat olduğunu vurgulamıştır. Gazetede Ermeni yazarlara korumacılık-liberalizm üzerine yazılar yazdırtmış ve bu yazılarla ülkenin iktisadi politikaları için serbest ticareti önermiştir. Ceride-i Havadis, sütunlarında ülkenin iktisadi sorunlarına değinmesi nedeniyle halkın konuştuğu ve ilgilendiği konulardan biri de ekonomi olmuştur.

1860 yılları ülkede gerçek anlamda gazetelerin çıkmaya başladığı dönemdir. Bu dönemde halk gazetelere rağbet etmeye başlamış ve gazetelerin çıkmasını sabırsızlıkla beklemiştir. Gazeteler kahvehanelerde okunmuş, okuma yazma bilmeyen kişiler de gazeteden istifade etmeye başlamış ve gazeteler halk yığınlarını yönlendirmede önemli bir güç olmuştur. Gazeteler güncel olaylar hakkında bilgi sahibi olmasını sağlamak yanında halkın bilgi seviyesini artırmayı da kendisine vazife edinmiştir. Bu özellik nedeniyle ülkedeki gazeteler bir okul gibi çalışmış ve halkın eğitim seviyesini yükseltmiştir. Gazetelerin değindiği konulardan biri de ekonomi olmuş, gazeteler sütunlarında ülkenin tüm iktisadi sorunlarına değinmiş ve halkın modern iktisadı öğrenmesi amacıyla bilgilendirici birçok yazı yayımlamıştır.

Bu çalışmada 1876 senesine kadar ülkenin kamuoyunu şekillendiren gazetelerdeki iktisadi haberlere değinilmiş ve gazetedeki yazılarla dönemin iktisadi anatomisi verilmeye çalışılmıştır. Çalışmada 1831-1876 döneminin iktisat dergileri ile dönemin en etkili siyasi gazeteleri incelenmiştir. Makalede incelenen Osmanlı Devleti süreli yayınları şunlardır: Takvim$i$ Vekayi, Le Moniteur Ottoman, Ceride-i Havadis, Ceride-i Ticaret, Tercüman-ı Ahval, Tasvir-i Efkar, Mecmua-i Fünun, Mir'at, Takvim-i Ticaret, Muhbir, Hürriyet, Terakki, Hadika, Ulum, Ibret, Şark ve Vakit'tir.

\section{Gazetelerin İktisadi Politikalara Bakış Açısı}

\subsection{Ekonomi İlminin Öğretilerek Halkın Ekonomi Bilincinin Artırılması}

Osmanlı Devleti'nde yayımlanan gazeteler halkın modern ekonomiyi öğrenmesini kendisine vazife edinmiş ve bu doğrultuda birçok yazı yayımlanmıştır. "Tedbir-i Ümran-ı Mülki" adlı ilk Osmanlı ekonomi kitabının bazı bölümlerinin 1833 senesinde Takvim-i Vekayi'de yayımlanmasıyla halka iktisat düşüncesi verilmeye çalışılmıştır (Ertuğ, 1970: 155). 1860 senesinde çıkan Tercüman-ı Ahval'in 119. sayısından itibaren Şerif Efendi'nin 'İlmi Emval-i Milliye" adlı iktisat kitabının tefrikası yapılmıştır. Kitap, soru-cevaplı konuşma diyaloglarından oluşmuş ve bu diyaloglarla Şerif Efendi halka ekonomi ilmini öğretmeye çalışmıştır (İskit, 1937: 23). Şerif Efendi, gazetede yayımladığı bir makalesinde iktisat biliminin adlandırılması 
meselesini tartışmış, bu ilmin üretim, dağıtım, mübadele ve tüketim olarak dört kısma ayrıldığını belirtmiş ve bunlar hakkında kısaca bilgi vermiştir (Yerlikaya, 1995: 60). 1862 senesinde çıkan Tasvir-i Efkar Şerif Efendi'nin Mekteb-i Mülkiye'de verdiği ders notlarını içeren kitabın tanıtımını yapmış ve ekonomi ilmi hakkında okurlarına bilgi vermiştir (Koloğlu, 2010: 155). 1872 senesinde çıkan İbret gazetesinde ise Reşad Bey, "Fenni Servet" adlı yazısıyla ekonomi ilmi hakkında okurlara bilgi vermiştir. İktisadi girişimlerin fenni servet doğrultusunda gerçekleştirilmesiyle verimin fazlalaşacağını ve bireylerin refahının artacağını vurgulamıştır (Reşad, 1872a: 1)

1868 senesinde Terakki gazetesinde Mehmet Mithat'1n "Ekonomi Tercümesi: Fenni İdare" iktisat kitabı tefrika edilmiştir ve bu kitap tefrikasıyla iktisadın halk tarafından bilinmesine çalışılmıştır (Mehmet Mithat, 1869: 1). Mehmet Mithat giriş yazısında ülkede daha önce yayımlanan iktisat kitaplarının belirli bir eğitim seviyesi olan kişilerin anlayacağı seviyede olduğunu ve halkın bu nedenle bu ilimden habersiz kaldığını belirtmiş ve kendisinin az okuması olan kişinin anlayabileceği bir üslupla bu kitabı yayınladığını ifade etmiştir (Mehmet Mithat, 1869: 1-2). 1873 senesinde çıkan Cüzdan dergisinde Reşad Bey'in "Tarik-i Refah" adlı iktisat kitabının tefrikası gerçekleştirilmiş̧ir ve bu tefrikayla halkın özel teşebbüs gerektiren girişimlerde çalışması teşvik edilmiş ve harcamaların tasarruf doğrultusunda gerçekleştirilmesi gerektiği vurgulanmıştır (Reşad, 1874: 22-28). 1873 senesinde çıkan Şark gazetesi ise ülkede ilmi servet bilinmedikçe ülkenin sanayi sektöründe gelişmesinin mümkün olmayacağını ifade etmiş, özellikle mali bürokratların bu ilmi teferruatlı bir şekilde öğrenmesi gerektiğini belirtmiştir. Bundan sonra gazete sütunlarında bu ilim hakkında okurların bilgilendirileceği ve yakında bir iktisat kitabının tefrika edileceği dile getirilmiştir (Şark, 1873c: 3).

Şerif Efendi, Tercüman-ı Ahval' de ayrıca ticarette önemli bir kavram olan kredi hakkında okurlarını bilgilendirmiş ve ticarette itibarın (güven) sadece iç ticarette uygulanmayıp dış ticaret işlemlerinde uygulandığını ve ticarete büyük bir yarar sağladığını bildirmiştir (Şerif Efendi 1861c: 2-3). Ülkede itibar sisteminin, Avrupa'da görüldüğü kadarıyla uygulanmadığını belirtmiş, bunun nedenini ise ticaretin gelişmemesi ile iç bölgelerde bankaların olmamasına bağlamıştır (Şerif Efendi 1861d: 2-3). Şinasi Tasvir-i Efkar' da yayımlanan bir yazısında ise ithalat ve ihracat defterlerinin tutulmasının ekonomi açısından yararlı olduğunu ve bu defterlerin düzenli tutulmasını istemiştir. Ülkelerde ithalat ve ihracat işlemlerinde defter tutulmasının ticarette ne kadar ürünün arttığı ve azaldığının bilinmesi açısından önemli olduğunu belirtmiştir (Şinasi, 1863b: 1).

1862'de çıkan Мeстиа-ı Fünun'da görülen iktisat yazılarında İngiliz iktisat düşüncesinin tesirleri bulunmaktadır (Sayar, 2006: 255). Münif Paşa, kaleme aldığ 1 ekonomi yazılarıyla Osmanlı klasik iktisadı olan "Ilm-i Tedbir-i Menzil" düşüncesini modern iktisat zihniyetiyle özdeşleştirmek ve bu bilimi halka öğretmek amacındaydı (Sayar, 2005: 146). 1860 senesinde Münif Paşa, "Ruzname-i Ceride-i Havadis'te önceleri "İdare-i Mülkiye" sonra ise "İlm-i Servet" tabirini verdiği ekonomi ilmi hakkında okurlarını bilgilendiren yazılar kaleme almıştır (İnceoğlu, 2005/2: 243). 1870 senesinden çıkan Hadika da okurların bilgi seviyesini artırmak için ekonomi ile alakalı kitapların tefrikasını gerçekleştirmiş̧tir. İstanbul'da kurulan bankaların işleyişi ve muamelatı hakkında ülkede Türkçe bir eser görülmediğini vurgulamış ve bu nedenle bankaların ortaya çıkışı, işleyişi ve faydaları hakkında sütunlarında genişçe bilgi vermiş ve banka hakkında bir kitabın tefrikasını gerçekleştirmiştir (Hadika, 1870: 5-6). Ayrıca Osmanlı tüccarların Avrupa'da yürütülen muhasebe işlemlerini bilmediklerinden ticari işlemlerde birçok müşküllerle karşılaştıklarını ifade etmiş ve tüccarlara muhasebe işlemleri hakkında bilgi verecek kitaplar tefrika etmiştir (Hadika, 1870: 195-196).

\subsection{Güncel Ekonomik Konular}

Osmanlı Devleti'nde yayımlanan gazeteler halkın güncel sorunlarına yönelik günlük ticari, borsa ve malların fiyatları hakkında bilgilendirici bilgiler vererek onların piyasa hakkında haberdar olmalarını sağlamıştır. Ülkede yayımlanan ilk gazete olan Takvim-i Vekayi piyasa 
bilgilerini “Ticaret ve Esar” üst başlığı altında vermiştir. Bu sayfada verilen ekonomi haberleriyle ülkenin iç tüketimini temin edecek bir ziraat üretimin olduğu ve ticaretin canlı olduğu vurgulanmak istenmiştir. Gazete, İstanbul'a birçok vilayetten zahire geldiğini, bu ticaretle uğraşanların üçte ikisinin Müslüman olduğunu belirtmiş ve bu haberlerle Müslümanların ticaretle ilgilendiğini göstermiştir (Koloğlu, 1981: 147-148). Gazete sütunlarında kahvenin üretildiği Haiti’de firtına yüzünden kahve üretiminin az olması sonucu piyasada darlığın yaşanacağı ve fiyatların yükseleceği ifade edilmiş ve bu gibi haberlerle dönemin tüketim madde fiyatlarının artış ve azalışları halka bildirilmiştir (Koloğlu, 1981: 149). Ülkenin serbest iktisat düşüncesi doğrultusunda buğdayda satış serbestliği getirdiği belirtilmiş, devletin artık zahire alımından vazgeçtiği ve bundan sonra halkın özgür iradesiyle zahiresini satabileceği ifade edilmiştir (Koloğlu, 2010: 133). Ceride-i Havadis gazetesi de Galata borsasındaki hareketler, yerli ve yabancı paraların iniş çıkışları hakkında günlük bilgiler vermiştir (Koloğlu, 2010: 146).

Ülkede ticaretin gelişmesi ve tüccar sınıfının menfaatini korumak amacıyla ticaret konusuna ağırlık veren Ceride-i Ticaret 1857 senesinde yayımlanmış, bu gazeteyle ülkedeki tüccarların birbirlerinden haberdar olmasının sağlanması ve üretilen ürünlerin tüm kesimlere duyurulması amaçlanmıştır. Gazeteyle tarım ürünleri satan tüccarlar bilgilendirilmiş, tarımsal ürünlerinin nerede ne miktarda üretildiği ve bölgelerde üretimin fazla veya noksan olduğu hakkında bilgiler verilmiş ve tüccarlar üretim konusunda doğru bilgilendirilmeye çalışılmıştır (Tekdemir, 2011: 212-213). Gazete sütunlarında kara ve deniz ticaretinde problemlerin çözümü konusunda yapılması gerekenler, ticari işlemlerde kanun ve kurallara özen gösterilmesi ve İstanbul'a giriş-çıkış yapan ticaret gemileri, taşıdıkları yük ve ürün fiyatları hakkında bilgiler yer almıştır (Iş̧k-Eşitti, 2014: 115). Ceride-i Ticaret, giriş yazısında derginin amacını ticaretin daha geniş alanlara yayılması, gelişmesi, tüccar ile müşterilerin düzenli bir şekilde bilgilendirilmesi ve ticarî alanda gerekli düzenlemelerin yapılmasına katkı sağlamak olarak açıklamıştır (Ceride-i Ticaret, 1857: 1). Dergide kara ve deniz ticaretine dair haberler ayrı sütunlarda verilmiştir. Bu sütunlarda taşra ticaret meclisinde görülen davalar, üretilen sanayi ürünlerinin fiyatları, iskeleler arasındaki süreler, tüccarlara gerekli olan ticarî haberler yer almıştır (Ceride-i Ticaret; 1857: 1-3; 1858: 1-3). İlanlar kısmında ise memlekete ithal edilen ürünlerin çeşitleri, miktarları ve fiyatları belirtilmiştir. Ayrıca İstanbul'a vilayetlerden ve dış ülkelerden gelen gemilerin, sayısı, çeşidi, yükü, menşei ve kaptanları hakkında bilgiler de verilmiştir (Ceride-i Ticaret, 1857:3-4; 1857: 34).

1862 senesinde çıkan Tasvir-i Efkar'ın giriş yazısında Şinasi, gazetenin bilim ve eğitimin gelişmesini sağlayacak ve ülkenin iktisadi ve sosyal sorunlarına değinecek bir politika güdeceğini belirtmiş ve gazetenin halkın anlaması için yazıların basit bir dil ve anlatımla verileceğini ifade etmiştir (Yanardağ, 2010: 6). Şinasi, gazete sütunlarında ihtiyaç sahiplerine sahip çıkılması, İstanbul'un çevre düzenlemesi, temizlenmesi, aydınlatılması ve ekonomi ilmi hakkında okurlarına öğretici yazılar yazmış ve dönemin sosyo-ekonomik sorunları hakkında okurlarını bilgilendirmiştir (Ülken, 2005: 41). Tasvir-i Efkâr, borsa ve piyasa haberleri yanında ekonomi ve maliye sorunlarına da değinmiştir (Sayar, 2006: 304). 1866 senesinde ülkede ticaretle uğraşan yabancı tüccarların öncülüğünde çıkan Takvim-i Ticaret'in yayım politikasına göre; gazete, ticaret, sanayi ve şirketler konusunda yayım yapacak, güncel siyasi ve dini sorunlara değinmeyecekti. Gazetenin her sayısında baş makale formatında ticaret ve sanayi hakkında makaleler yayımlamıştır (Nalcıoğlu, 2013: 302). Ayrıca gazete sütunlarında ticaret, pamuk ziraatı, menafi sandıkları, şirketleşme, banka, mesleki eğitim, demiryolları, nüfus ve sergi gibi konular hakkında yazılar görülmüştür (Yazıc1, 1999: 62). Takvim-i Ticaret, Avrupa'daki mali buhran ve borsa haberleri hakkında okuyucularını bilgilendirmiștir (Takvim-i Ticaret, 1866e: 4). İstanbul'daki borsa ve banka faaliyetleri hakkında bilgi vermiş, devletin yapacağ 1 istikrazlar hakkındaki varsayımları aktarmış ve hisse senetlerinin ne olacağı hakkında bilgi vermiştir (Takvim-i Ticaret, 1866f: 4). İstanbul ticareti hakkında da okuyucularına bilgi vermiştir. Piyasada manifatura, şeker ve kahve gibi ürün miktarının az olduğu, kahve, şeker ve pirinç fiyatının arttığı, İngiliz ürünlerin rağbet gördüğü belirtilmiştir (Takvim-i Ticaret, 1866h: 4). 
1868 senesinde yayımlanan Terakki gazetesi de sütunlarında kara ve demiryolları, şirket, ziraat, ticaret, sanayi ve bankacılık gibi iktisadi konularda yazılar görülmüştür (Şener, 1994: 233). 1873 senesinde çıkan Şark sütunlarında İstanbul borsa piyasasının durumu hakkında bilgiler paylaşmış (Şark, 1874d: 2) ve bir sayısında Osmanlı Bankası ile hükümet arasında yapılan müzakereler sonucu Galata borsasındaki banka hisse fiyatlarının Avrupa piyasalarına göre yükseldiğini ancak eshamı umumiye fiyatlarında önemli bir değişmenin yaşanmadığı belirtilmiştir (Şark, 1875: 1). Gazetenin üçüncü bazen de dördüncü sayfasında Galata Borsası ile Londra Borsası'nın esham-1 umumiye fiyatları her gün verilmiştir (Şark, 1874e: 3). Ayrıca gazetede İstanbul'a gelen emtia malların fiyatları hakkında bilgiler de verilmiştir (Şark, 1874f: 3). 1875 senesinde çıkan Vakit gazetesi de vilayetlerdeki ekonomi haberlerine değinmiştir. Halep'te tahıl üretimin fazla olması nedeniyle fiyatların düştüğünü, Antalya limanına yabancı gemilerin uğramasının ticareti canlandırdığını ve Antalya'da çekirge felaketinin ziraatı olumsuz etkilemesi gibi haberlerle halkın vilayetlerin ekonomisi hakkında bilgi sahibi olmasına çalışmıştır (Yerlikaya, 1996: 82-83).

\section{3. İktisadi Politikalar ve İktisat Düşüncesi}

Osmanlı Devleti'nin iktisadi politikalarının herhangi bir düşünce doğrultusunda olmasını belirten yazılar birçok gazetede vurgulanmıştır. $\mathrm{Bu}$ yazıların çoğunluğunda serbest ticaret düşüncesi bir sistem olarak önerilmiş ve örnek ülke de İngiltere gösterilmiştir. Bu konuyu en fazla dile getiren gazete Ceride-i Havadis olmuştur. Gazetede Ermeni kökenli Osmanlı vatandaşları aracılığıyla korumacılık-serbestlik tartışması yapılmış ve Osmanlı Devleti'ne serbest ticaret politikaları önerilmiştir (Mardin, 1990: 60-61). Gazete, 1860 senelerinde de belirgin bir şekilde İngiliz ekonomi çıkarları doğrultusunda ekonomi yazılarına ve haberlerine yer vermiştir (Koloğlu, 2010: 146). Gazete sütunlarında, ticaret ve sanayisi gelişmiş ülkelerle gelişmemiş ülkeleri karşılaştırarak servet kaynağ 1 olarak ticaret ve sanayinin gelişmişliği gösterilmiş, ülke kalkınmasında bu iki faktörün belirleyici olduğu ifade edilmiştir (İnceoğlu, 2005/2: 251).

1863 senesinde çıkan Mir'at dergisi ülke kalkınması için örnek gösterdiği İngiliz devletinin eğitim ve sanayide ilerledikten sonra ticaretin geliştiğini bu cihetle ziraat ve sanayi ürünlerinin uluslararası piyasada itibar bulduğunu ifade etmiş̧tir. Bir ülke ihracatının ithalattan fazla olması gerektiğini belirtmiştir. Sanayisi gelişmiş bir milletin ham eşya ithalatının fazla olmasının o ülkenin kalkınması sonucu olduğunu, İngilizlerin zahire, pamuk ve ipek gibi ham eşyaları diğer ülkelerden satın aldığını, hariçten yirmi kuruşa aldıkları pamuğu ülkelerinde işledikten sonra iki yüz ile üç yüz kuruşa kadar sattıklarını belirtmiştir. Bu doğrultuda ülke kalkınmasında İngiltere'yi örnek göstermiş ve ülke üretiminin artırılmasını istemiştir (Mir'at, 1863: 5-11).

1873 senesinde İtalyan asıllı Bordiyane tarafından yayımlanan Şark, iktisadi ve mali konuların işlendiği dönemin önemli gazetelerindendir (Baykal, 1990: 80). Gazetedeki yazılarda iktisadi liberalizmin tutarlı bir şekilde verildiği gözlenmektedir. Ülkede doğal kaynaklarının ihtiyaçlar nispetinde ve halkın çalışkan olduğu ama üretimde doğal ve toplumsal faktörlerinin uyumsuzluğundan kaynaklanan bir düzensizlik nedeniyle gerekli verimin elde edilemediği ifade edilmiştir. Üretimin artırılması için mülkiyet ve kişi özgürlüğün önündeki engellerin kaldırılması gerektiğini savunmuş, yatırımlar için şirketlerin yaygınlaşması gerektiği vurgulanmıştır. Ekonomi yazılarında genel olarak devletin, fert ve toplum güvenliğini sağlanması istenmiş ve hukuk düzeninin kurulması gerektiği ifade edilmiştir (Şener, 1994: 235-236). Ülkede devletin sanayi ve ticarete destek çıkmasını eleştirmiş, devletin bu gibi iktisadi faaliyetlere karışmasının iktisat ilmince uygun olmadığını ifade etmiştir. Devletin sanayi ve ticaret hatta inşaat faaliyetlerini girişmemesini istemiştir. Ülkede sanayi, ticaret ve inşaat sektörü için gerekli olan sermaye sorununun ülkeye yabancı sermayenin teşvik edilmesiyle giderileceğini belirtmiş ve bu doğrultuda yabancı sermayenin ülkeye girmesi için uygun ortamın yaratılmasını istemiştir (Şark, 1874a: 1). 
Yurt dışına kaçan Osmanlı aydınları tarafından çıkarılan Hürriyet gazetesinde ülkenin iktisadi sorunları hakkında birçok yazı yayımlanmıştır. Kemal, Hürriyet sütunlarında Hristiyan devletlerin Osmanlı'yı iktisadi olarak nüfuzları altına almak istediğini ifade etmiş, ithalatın çoğalmasının ülkeye iktisaden zarar verdiğini belirtmiştir. Ülkenin bu durumdan kurtulması için hammaddelerin imal edilerek Hind ve Çin bölgelerine ihraç edilmesini istemiş, bundan ülkenin kazanç elde edeceğini dile getirmiştir (Ülken, 2005: 109). Kemal'in değindiği bir diğer iktisadi sorun ülkenin iktisadi vaziyetidir. Kemal, devletin sanayi, ticaret ve ziraattan yeterince istifade edemediğini belirtmiş̧, yanlış iktisadi politikaları sonucu ülkenin bu hale geldiğini ifade etmiş, bu durumdan kurtulmak için verimi artıracak politikalar güdülmesini istemiştir (Sungu, 1999: 825). Askerliğin gayrimüslime zorunlu olmasıyla Müslüman nüfusun azalışını engelleyeceğini, üretimde ve ticarette Müslümanların da var olabileceğini ifade etmiş, üretimi tahrip eden vergilerin kaldırılmasını ve sanayinin gelişmesi için bir milli bankanın kurulmasını istemiştir (Mardin, 2002: 356).

Terakki gazetesinde Nurettin Bey, Kırım Harbi, 1861 ticaret anlaşmasıyla verilen imtiyaz ve milli sanayinin kurulmasına çalışılmaması, inhisar sistemi, gümrük mevzuatı ve insanı bask1 altına alan bazı kurumlar gibi nedenler yüzünden ülkenin geri kaldığını belirtmiştir (Nureddin 1869a: 2). Bu duruma çözüm getirmek için anlaşmaların tadil edilmesi, imtiyazların kaldırılması, sanayinin ıslah edilmesi ve yerli malı kullanmayı teşvik edilmesi gerektiğini ifade etmiştir (Sayar, 2006: 262). Gazetenin diğer yazarı Hayrettin Bey ise, modernleşmede Fransız tarzı yerine İngiliz tarzı modernleşme gerçekleştiği takdirde ülkenin kalkınacağını belirtmiş ve İngiliz iktisat düşüncesinin yayılmasıyla bunun gerçekleşeceğini ifade etmiştir (Sayar, 2006: 301). Servetin kazanılması ve harcanmasında itidal gösterilmesini istemiştir. Sermayedarın servet ve kazancını lüzumlu bir şekilde harcanmasını sağlayacak bilgi ve birikimin ancak eğitimle sağlanacağını ifade etmiştir (Hayrettin 1869: 1-2).

Ülkenin iktisadi politikalarına serbest iktisat düşüncesinden farklı bir şekilde olmasını savunan tek yayın organı Hadika gazetesidir. Gazete ekonominin milli bir yaklaşımla ele alınmasını savunmuş ve ülkede yerli mallara rağbet edilmesini istemiştir. Hadika ülke içerisinde tek mezhep olarak ittifak edilmediği sürece o millette ayrıllğın yaşanacağını ve ülkenin iktisadi gerilemenin ise bundan kaynaklandığını vurgulamıştır. Bir milletin iktisadi gücünün tek mezhep ve lisan halinde yaşamasıyla gerçekleşeceğini belirtmiştir. Yerli ürünlerin kullanılmamasının sebebini ülkede görülen ayrılığa bağlamış ve "efkâr-ı milli" olsaydı ülkenin geri kalmayacağını vurgulamıştır (Hadika, 1870: 56). Ermeni ve Rum milletinden hangi esnaf olur ise olsun milletin bu esnaflardan alışveriş yaptığını kendi milletinin esnafını tercih ettiğini vurgulamıştır. Gayrimüslimlerin kendi esnafından alışveriş yaparak sanatını geliştirdiğini ve bir araya gelerek şirketler kurduklarını belirtmiştir (Hadika, 1870: 63-64). Ülke ürünlerine olan rağbetsizliğin sanatın azalmasına sebep olduğunu ve bunun nedenini ise ülkede "İttihadı Efkâr-ı Milliye"nin olmamasını göstermiştir (Hadika, 1870: 64). Devlet fabrikalarının kötü yönetildiğini belirtmiş ay sonunda alacağ1 maaşı düşünen memurların bu tarz fabrikalarda yönetici ve işçi olarak çalıştırılmasına karşı çıkmıştır. Memurlar tarafından işletilen fabrikalarda hiçbir zaman ilerlemenin görülmeyeceğini vurgulamıştır (Hadika, 1870: 302).

\subsection{Tarımsal Kalkınma}

Osmanlı Devleti'nin iktisadi kalkınmasının ancak üretim artışı ile gerçekleşeceğini farkına varılmış ve bu nedenle ülkenin önemli servet kaynaklarından biri olan ziraat sektörü gazetelerin en fazla değindiği iktisadi konu olmuştur. Takvim-i Vekayi'de yayımlanan bir yazıda, ülkenin iktisadi kalkınmasında ziraatın önemli güç olduğu belirtilmiş ve ülkenin verimli arazilerinden dolayı ülkede tarımsal kalkınmasının gerçekleşmesinin doğru bir politika olduğu ifade edilmiştir. Devletin de zirai kalkınma için çiftçilere ucuz kredi temin ettiği ve çiftçilerin tefecilere müracaatını azalttığı belirtilmiştir. Ayrıca Tanzimat'ın ilan edilmesiyle ülkede zirai üretimin artığ1 ve önceki döneme göre devlet gelirlerinin üç kat arttığ 1 ifade edilmiştir. Ülkede ihracatın artırılmasının tarımsal ürünlerle gerçekleşeceğini vurgulamış ve ülke sanayisinin 
Avrupa ülkelerine göre geri olması nedeniyle Avrupa'ya endüstri ürün ihracının gerçekleşmesinin zor olduğu vurgulanmıştır (Kurdakul, 1997: 248-249).

Ülkenin iktisadi gelişmesinin ancak tarımsal kalkınma doğrultusunda olacağını vurgulayan en önemli yayın organı Ceride-i Havadis'tir. Gazetenin sahibi Churchill, Osmanlı ülkesinin servet ve zenginliğinin ana kaynağının ziraat olduğunu belirtmiş, ziraat sayesinde devlet hazinesinin dolu olduğunu vurgulamıştır. Osmanlı Devleti'nin de ziraatın öneminin farkında olarak çaba gösterdiğini ve Meclis-i Umur-1 Nafia'yı tesis ettiğini söylemiştir. Bu meclisin ziraatın teşvik edilmesi hususunda birçok girişimi gerçekleştirdiğini, ziraatta lazım olan her türlü alet ve edevatı tedarik ettiğini ve gerekli diğer ziraat tedbirlerini de aldığını belirtmiştir (Ceride- $i$ Havadis, 1840a: 2). Ülkede devletin tekelleri kaldırması ve tarımsal ürünlerin ihracatına izin vermesini onaylamış, bu politikanın ülkenin tarımsal kalkınmasına olumlu katkı sağlayacağını dile getirmiştir. Devletin karışmadığı sürece piyasanın kendiliğinden dengeye geleceğini, bolluğun yaşanacağını ve ucuzluğun sağlanacağını belirtmiştir. Tanzimat'ın ilan edilmesinden bu yana ülkede tarımsal ticaretin geliştiğini vurgulamıştır (Ceride-i Havadis, 1840b: 3).

Churchill, Osmanlı'nın bir tarımsal ürün ihracatçısı olmasını İngiliz endüstri sınıfının görüşü doğrultusunda savunmuştur. Tarımsal ihracattan elde edeceği kazançla İngiliz sanayi mamullerinin piyasasının artacağı düşüncesi fikrini şekillendirmiştir (Mardin 1994: 60-61). İngiliz parlamentosundaki tarım-sanayi tartışmalarını da Ceride-i Havadis'te vermiş, Ricardo'nun İngiltere'de tarımsal ürünlerin ithalinin serbest edilmesine vurgu yapmıştır (Sayar, 2000: 274). İngiltere'ye olan ipek ihracının arttığını belirten Churchill, İngiliz sanayisinin pamuk açığını gidermek için ülkede pamuk üretiminin artırılmasına yönelik yazılar yayımlamıştır (Koloğlu, 2010: 136). Ülkede pamuk ziraatını teşvik etmiştir. Avrupa ülkelerinin pamuğa olan talebinin fazla olduğunu, Osmanlı'dan gelen pamukların da rağbet gördüğünü, bunun daha da artması için devletin bu konuda say u gayret etmesini ve çiftçileri teşvik etmesini istemiştir (Ceride-i Havadis, 1840e: 2). Ziraatın önemini belirtmek için kalkınmış İngiltere örneğini vererek ziraatın İngiliz ekonomisine olan katkısını anlatmıştır (Ceride-i Havadis, 1841: 2). Ülkede sermaye birikiminin kaynağı olarak ziraat sektörünü önermiştir. Osmanlı'nın yönetilmesi için lazım olan sermayenin tarımdan elde edilebileceğini sermayenin oluşmaması halinde dışarıdan bir ürünün alınamayacağını belirtmiştir (Ceride-i Havadis, 1842: 1). Devletin ülke ziraatına destek vermesi gerektiğini, ülke topraklarının ziraat edilip edilmediğini kontrol etmesini ve gerekli aksaklıkları tespit edip çözmesi gerektiğini ifade etmiştir (Ceride-i Havadis, 1843: 1).

Churchill, Osmanlı Devleti'nin 1840'lardaki sanayileşme politikasının yanlış olduğunu belirtmiş, bu doğrultuda gazetede zirai kalkınmayı savunmuştur. Sanayileşmesinin önemli olmasına karşın ülkede birçok verimli arazinin ekilmeden durduğunu ve tüm yiyecek ürünlerin hariçten karşılandığını bu doğrultuda ülkede fabrikalaşmak yerine ziraat sektörüne yatırım yapılmasını istemiştir (Ceride-i Havadis, 1840c: 2). Osmanlı'nın ziraatını çoğaltıp bununla sanayi ürünlerini değiş̧tirdiği vakit ülkede fiyatların ucuzlayacağını söylemiş, bu yöntemle büyük karlar elde edileceğini dile getirmiştir (Ceride-i Havadis 1840c: 2). Bir ülkenin uzman olduğu işi terk edip yeni bir sektörde say u gayret etmemesi gerektiğini vurgulamıştır. Osmanlı'nın çuka ve bez gibi sanayi ürünü üretmek niyetinde olduğunu ancak pamuk, ipek ve diğer zirai ürünleri üretip bunları Avrupa'ya satarsa elde edeceği kazançla Avrupa'dan daha ucuz bez ve çuka gibi ürünleri temin edebileceğini ifade etmiştir. Tanzimat'in ilan edilmesinden sonra yaşanan istikrar düzeninden istifade ederek ziraatına öncelik verip ilerletilmesini ve ziraattan elde edeceği kazançlarla vakit vakit fabrikalar tesis etmesinin daha uygun olacağını belirtmiştir (Ceride- $i$ Havadis, 1840c: 3).

Takvim-i Ticaret gazetesinde ülkenin önemli ihraç maddesi olan pamuk ziraatı hakkında birçok makale görülmüştür. Gazete yazılarında ülkenin bazı bölgelerinde ziraatı önemli olan pamuğun dokuma sanayisinde kullanımı nedeniyle üretimin önem arz ettiği ifade edilmiştir (Takvim-i Ticaret, 1866d: 1-4). Başka bir yazıda pamuk ziraatının buğday ziraatından verimli olduğu belirtilmiş, çiftçinin bundan büyük kazanç elde edeceği, pamuk ihracının Amerika'daki konjonktürden etkilenmeyeceği ve Amerika'da barış sağlansa bile pamuk ihracatının artacağ 1 
vurgulanmıștır (Birinci, 1938: 133-134). Diğer bir yazıda ise pamuk ihracında tüccarların suiistimallerde bulunduğu ifade edilmiş, bundan ülke ticaretinin olumsuz etkilendiği ve Liverpool ile Manchester tüccarlarının bu durumdan rahatsız olduğu dile getirilmiştir (Birinci, 1938: 136). Takvim-i Ticaret, ekonominin gelişmesi için başta ziraat sektörü olmak üzere mesleki eğitimin yaygınlaşmasını istemiş, ülkenin dış ticaret dengesinin ziraatın ilerlemesiyle gerçekleşebileceğini vurgulamıştır (Takvim-i Ticaret, 1867b: 1). Terakki ise Osmanlı'nın ilerlemesi için ziraatın ıslah edilmesini istemiş ve çiftçinin modern fenni usulleri tatbik etmek amaciyla numune çiftliklerin açması gerektiğini vurgulamıştır (Terakki, 1870a: 2). Hadika ise ülkenin bir ziraat ülkesi olması için ülkede her çeşit ziraat mektebinin açılması gerektiğini savunmuştur (Hadika, 1870: 86-87).

Namık Kemal, Ibret gazetesinde ülkenin kalkınması sürecinde ziraatın ticaret ve sanayiden daha önemli olduğunu belirtmiş, bu nedenle ziraatın geliştirilmesine önem verilmesini istemiştir. Ülkedeki tarımsal işletmelerin modern ziraat yöntemlerle yapılmasını ve ülkede ziraat uzmanları öncülüğünde numune çiftliklerin teşkil edilmesini istemiştir. Ziraatın geliştirilmesindeki sorunlardan birinin de sermaye sıkıntısı olduğunu belirtmiş, çiftçilerin tefecilerin ellerine mahkûm kaldığını ve bunun ülke ziraatının gelişmesini engellediğini vurgulamıştır (Namık Kemal, 1872a: 1-2). Dönemin diğer gazetesi Şark ise, devletin önemli gelir kaynağı olan tütünden daha fazla istifade etmesi için tütün vergisinin inhisar yöntemiyle toplanmasının uygun olacağını belirtmiş ve bu yöntemin devletin uygulamasının sakıncalarını belirttikten sonra bu inhisarın özel bir şirkete verilmesini istemiştir (Şark, 1874c: s.1).

Vakit gazetesi devlet borçlarını ödemek için ülkenin servet kaynaklarından istifade edilmesi gerektiğini vurgulamış ve bu doğrultuda gazetede "Hıtta-i Irakiyyenin Islahatı" başlıklı bir yazı dizisi yayımlanmıştır. Bu yazı dizisinde Irak'ın verimli toprakları olduğu ve bu topraklardan istifade etmek için göçebe halkın iskân ettirilmesi, demiryolunun inşa edilmesi ve nehirlerden istifade edilmesi için barajların yapılması istenmiştir (Yerlikaya, 1996: 71-72). Gazete, ülkede ziraatın daha fazla istifade edebilmesi için ziraatin makineleşmesini, demiryollarının yaygınlaştırılmasını ve iktisadi eğitim veren mesleki eğitim kuruluşlarının artırılması gerektiğini belirtmiş ve bütçede bu gibi kalemlerin kısılmasına karşı çıkmıştır (Yerlikaya 1996: 82).

\subsection{Sanayileşme}

Osmanlı Devleti'nde 1830'lardan sonra sanayi üretimin gerilemesi ve birçok sanayi atölyelerin kapanması nedeniyle ülkede sanayi üretimin gerçekleşmesi için birçok teşvik edici yazı yayımlanmış ve Avrupa'nın bugünkü iktisadi başarısının nedeni olarak sanayideki gelişme gösterilmiştir. Takvim-i Vekayi gazetesinde 1846 senesinde yayımlanan bir makalede İngiltere'de sanayinin gelişme süreci anlatılmış, bir ülkede insanların sanayi ve ticarete rağbet gösterdiği sürece o ülkede refahın görüleceği ifade edilmiştir (Kurdakul, 1997: 247-248).

Tercüman-ı Ahval sanayileşmeyi savunan bir yayım politikası izlemiştir. Gazetede Şerif Efendi ülkenin sanayileşme sorunlarına değinmiştir. Gazete, İngiliz menfaatine uygun olarak ülkenin ziraat alanında kalkınmasını öne sürenlere karşı sanayileşmeyi savunmuştur. 1838 ticaret anlaşmasının ülke sanayisinin yok olmasına neden olduğunu belirtmiştir (Yerlikaya, 1995: 60). Şerif Efendi, Osmanlı toplumunun sanayi ve ticaret karşısında Avrupa milletlerinin aksine pasif bir davranış içerisinde olmasını eleştirmiştir (Sayar, 2006: 310). Ülkenin Avrupa ülkelerine göre sanayi sektöründe geri olmasına karşın ülkenin kısa sürede bu açığı kapatacak potansiyele sahip olduğunu belirtmiştir (Fındıkoğlu, 1943: 264-265). Devletin kalkınması için sanayi sektörüne daha fazla ağırlık vermesini tavsiye etmiştir (Şerif Efendi, 1861a: 3-4). Batı ülkelerinin sanayi sektöründe uzun yıllar say u gayret edip kalkındıklarını, Osmanlı'nın da say ederek sanayide kalkınabileceğini vurgulamıştır. Sanayinin gelişmesiyle servetin oluşacağını ve bu doğrultuda ele geçen sermayeyle zirai kalkınmanın mümkün olacağını belirtmiştir (Şerif Efendi, 1861b: 2-3).

Terakki gazetesinde Nurettin Bey, ülkede sanayileşmenin geri kalmasının nedenlerine değinmiş ve bir yazısında Fransız iktisatçı Say'ın usta ve esnaf üzerine görüşlerine değindikten sonra ülkedeki esnaf kurumunun rekabeti engellediğini vurgulamıştır. Rekabetin engellendiği bir 
ortamda iktisadın kalkınamayacağını bu nedenle esnaflık kurumun kaldırılmasını dile getirmiştir. Bunun yerine halkın sermaye teşekkül ederek sanayi şirketleri ve emniyet sandıklarının kurulmasını istemiştir (Sayar, 2006:245). Ülkede sanayide iş bölümünün gelişmemiş olması nedeniyle üretimin düşük kaldığını belirten Nurettin Bey iş bölümünün oluşması için ustaların bildiklerini işçilere öğretmesi gerektiğini vurgulamıştır (Nureddin 1869b: 4-5).

Terakki'de imzasız çıkan başka bir yazıda ise halkın sanatını koruyacağı bir kanunun olmaması ve geleceğe güven duymaması gibi nedenler sonucu sanayinin ilerlemediğini belirtmiştir (Terakki, 1870b: 3-4). Sanayi ile uğraşanların bir araya gelip şirket kurması gerektiğini vurgulamış, yerli ürünlerin ecnebi ürünlere göre maliyetli üretildiğinden sanayi tesislerin kapandığını belirtmiş, bu durumdan kurtulmak için üretimin modern makinelerle yapılmasını istemiştir (Terakki, 1869r: 1-2). Avrupa'ya sanayi ilmini öğrenecek öğrencilerin gönderilmesi ve Avrupa'dan uzmanlar getirterek yerli ustaların modern sanayi teknolojileri öğrenmeleri için devletin yardımcı olması gerektiğini belirtmiştir (Terakki, 1870c: 2). Ülkede sanayinin gelişmesi için modern makineleri kullanacak nitelikli iş̧̧inin olması gerektiğini vurgulamış ve bu doğrultuda devletin bir an önce mesleki eğitim kurumlarının tesis etmesini istemiştir (Terakki, 1869c: 2).

Hadika gazetesi ise ülkede önceleri giyecek elbiselerden ev döşemelerine ait tüm eşyaların üretildiğini ve dışarıya muhtaç olmadan idare edildiğini ancak bugünlerde bu malların ülkede rağbet görmediğini Avrupalıların ülkeye getirdikleri ürünlerin çoğaldığını ve halk tarafından rağbet gördüğünü ifade etmiştir. Halkın yabancı mallara olan rağbetin sonuçlarını düşünmediğini zamanla yerli sermayenin Avrupa'ya akarak ülkenin fakirleştiğini belirtmiştir. Avrupa eşyasına rağbet olunduktan sonra ülke mallarının alınmamaya başlandığını ve bu nedenle bunları üreten ustaların sanatlarını terk ederek işçilik yaptığını bildirmiştir. Halkın Avrupa ürünlerini aldıkça ülkede sanayinin ilerlemeyeceğini hatta daha da gerileyeceğini belirtmiştir (Hadika, 1870: 38-39). Sanayinin gelişmesinin yerli ürünlerin kullanılmasıyla olacağını ve yerli ürünlerin kullanılmasıyla bu ürünlerin ülkede kabul görüp yaygınlaşacağını belirtmiştir. Yerli ürünlerin kullanımı için halkın birbirini teşvik etmesi gerektiğini bu teşvik sayesinde yerli ürün kullanımının artacağını vurgulamıştır. Osmanlı'da üretilen bir malın hariçten gelen mala göre fiyatın iki kat fazla olmasına karşın yerli malın kullanılmasını tavsiye etmiş ve yabancı mal kullanımı devam ettiği sürece bundan halkın da zarar göreceğini belirtmiştir. Yerli mala rağbet edip kullanmanın ittifak ile olacağını ve ülkede sanayinin gelişmesinin ancak 'İttihad-ı Efkar-ı Milliye' ile gerçekleşeceğini ve devletlerin gelişmesinin esas nedeninin bu olduğunu ifade etmiştir (Hadika, 1870: 46-48). Ayrıca ülkede açılan kız sanayi mektebine genelde gayrimüslimlerin talep ettiğini belirtmiş Müslüman çocukların bu mekteplere gönderilmesini istemiştir (Hadika, 1870: 37-38). İbret'te yazdığ ülkeye yabancı ürünlerin istilasının duracağını belirtmiştir. (Namık Kemal, 1872b: 1).

1870 senesinde Ali Suavi tarafından çıkarılan Ulum gazetesi ülkede sanayileşmenin gerçekleşmemesi nedeni olarak toplumdaki değer yargıları olduğunu belirtmiştir. İslam'ın sanayiye değer verdiğini ve her büyük zattın bir sanatla isminin anıldığını ifade etmiştir. Türklerde öteden beri bir paşa bir ağa olma hevesinin olduğunu, beşikteki çocuklara bile kâtip olur paşa olur diye dua edildiğini halkın hükümet kapısından maişetini gidermekten başka bir şey düşünmediğini belirtmiştir. Müslümanların hazineye ağız açtığından bu yana ülkede muhtaç olunan zanaatların Hristiyan milletlerine geçtiğini dile getirmiştir. Zanaata rağbetsizlik sürdükçe elde kalan manav ve bakkalcılık gibi mesleklerin bile yabancıların eline geçeceğini belirtmiştir (Ali Suavi, 1870: 727-732).

Şark gazetesi potansiyelinin olmaması nedeniyle ülkenin sanayileşmesine karşı çıkmıştır. Gazete medeniyetin sanayileşme sonucu elde edildiğini belirtmiş ve sanayinin en önemli güç kaynağı olduğunu vurgulamıştır. Bir ülkede sanayinin gelişmesinin eğitimle elde edildiği ve ürün maliyetinin düşürülmesi için üreticileri rekabet ettiğini ifade etmiştir. Bunun sonucunda ise büyük makinelerin icat edildiğini ve sanayi ilminin geliştiğini belirtmiştir. Sanayinin az olması ve halkın bu mesleğe rağbet etmemesi gibi hakikatler ortada iken bazı kişilerin ülkede sanayileşmenin 
gerçekleşmesini istemesinin hayalperestlik olduğunu ifade etmiştir. Ülkenin gelişmesi için çıkar yolunun tarımsal üretimi artırmak ve ülkede maarifin gelişmesini çalışmak olduğunu dile getirmiştir (Şark, 1873b: 1).

\subsection{Ticaretin Geliştirilmesi ve Serbest Ticaret}

Gazetelerin en fazla değindiği konulardan biri de ticaret olmuştur. 1838 senesinde İngiltere ile imzalanan serbest ticaret anlaşmasıyla ülkede serbest ticaret ilkelerinin uygulanması ve bu ilkelerin ülkelerin ekonomisine olan yararlarını belirten yazılar gazetelerde görülmüştür. Takvim-i Vekayi'nin Fransızca eki olarak 1831 senesinden yayımlanan Le Moniteur Ottoman gazetesinde David Ross tarafından yazılan "Osmanlı Topraklarında Ticaret Özgürlüğü Konusunda" başlıklı makalede ülkede ticaretin önemli bir iktisadi etkinlik ve ticarette özgür bir ortamın olduğu ve ticareti engelleyici herhangi bir yasağın olmadığı vurgulanmıştır. Küçük bir gümrük vergisi haricinde malların ülke pazarına girildiği ve yabancı tüccarlara karşı saygılı olunduğu ifade edilmiştir (Koloğlu, 1998: 72-74). Ottoman'ın sütunlarında David Urquhart'in "Türkiye ve Kaynakları" adlı eserinin bazı bölümlerini yayımlamıştır. Urquhart, İngiltere'nin Rusya'dan ithal etmek zorunda olduğu ürünlerinin Türkiye'den temin edilebileceğini belirtmiş ve bu doğrultuda İngiliz-Osmanlı dış ticaretinin geliştirilmesini savunmuştur. Osmanlı'nın İngiliz ticaret çıkarları doğrultusunda yeniden organize edilmesini ve bu doğrultuda bir anlaşmayla gümrük vergileri, dahili vergiler ve tekel sisteminin kaldırılması gerektiğini ifade etmiştir (Koloğlu, 1998: 75). Blak Bey ise, gazetede Osmanlı'da serbest ticaret sisteminin uygulanmas1 gerektiğini savunmuş ve ülkenin geri kalmasının sebebi olarak da devlet tekellerini göstermiştir. Ülkede ticaret serbestliği için borsanın kurulmasına çalışmıştır (Koloğlu, 2000: 44-45). Osmanlı ekonomi politikalarının serbest iktisat düşüncesi doğrultusunda şekillendirilmesine çalışmış, bu sistemin kabulüyle üretimin artacağını ve kalkınacağını ifade etmiştir (Koloğlu, 1988: 18).

1838 ticaret anlaşmasının imzalandığı sene, İstanbul'da ticaretle uğraşan ve bazı İngiliz ticaret evlerinin temsilcisi olan Churchill adlı bir İngiliz vatandaşı, av esnasında kazara bir çocuğu vurması sonucu tutuklanmıştır. Bunun yarattığ 1 tepki karşısında Churchill'e ülkede gazete çıkartma yetkisi verilmiş ve Ceride-i Havadis bu olay sonucu çıkmıştır (Berkes 1976: 331). Churchill, gazetede İstanbul'da ticaret işlerinden anlayan ve ekonomi bilen Ermeni yazarlarını gazetede istihdam etmiştir. Ermeniler aracılığıyla gazetede korumacılık-liberalizm tartışmasını yapmış ve ülkenin iktisadi politikaları için serbest iktisat düşüncesini önermiştir (Berkes, 1976: 331). Ceride'nin ilk sayısından itibaren devletin iktisat politikası için serbest iktisat düşüncesini bir model olarak öne sürmüştür. İltizam ve zahire ihraç yasağının kaldırılmasına yönelik olumlu yazılar yayımlamıştır (Koloğlu, 2010: 135). Ülkede sektörel olarak tarımsal kalkınmayı savunduğu gibi bu konu ile alakalı olan serbest ticaret ortamının da yaygınlaşmasını istemiştir. Ticarete önem vermeyen milletlerin kuvvetli olamayacağını ticarete ne kadar itibar edilirse ülke kuvvetinin o nispette artacağını ifade etmiştir (Ceride-i Havadis, 1840d: 2).

Ülkede ticaretin gelişmesini sağlamak ve tüccarları ticari konularda bilgilendirmek amacıyla yayımlanan Takvim-i Ticaret, bir ülke refahının en önemli sebeplerinden birinin de ticaretin gelişmesi olduğunu ve ticaretin gelişmesi için kurumların gelişmesi kadar tüccarların da faaliyetleri layıkıyla icra etmesinin önemli olduğunu vurgulamıştır (Takvim-i Ticaret, 1866i: 1). Bir ülkede ticaret ve sanatın gelişmesi için cemiyetin kurulmasının önemli olduğunu ve İstanbul'da Cemiyet-i Ameliperver namıyla bir cemiyetin kurulduğunu belirtmiştir (Takvim-i Ticaret, 1866a: 1). Bir ülkede ticaretin kolaylaşması için bankaların kurulmasının da önemli olduğunu bu nedenle devletin bazı vilayetlerde kurulan menafi sandıklarının ülkenin her tarafinda kurulması için büyük çabalar gösterdiğini ifade etmiştir (Takvim-i Ticaret, 1866b: 1). Başka bir yazıda ise ticaretin bir ülkenin başlıca servet kaynağından biri olduğu ve tüccara ne kadar değer verilirse o ülke servetinin çoğalacağı belirtilmiştir. Bir ülke halkının ticarete ilgisiz kalmasının o ülke ticaretinin ecnebiler tarafından idare edilmesine yol açacağını vurgulamıştır. Halkın ticarete rağbet etmemesinin üzücü bir durum olduğunu ve ülke ticaretinde yabanciların etkinliğinin fazla olduğunu ifade etmiştir (Takvim-i Ticaret, 1867a: 1). 
1860'ların ikinci yarısından itibaren gazetelerde serbest ticaret politikalarını zararlarına değinen yazılar görülmeye başlamıştır. Namık Kemal, Hürriyet gazetesinde yayımlanan bir yazısında serbest ticareti ilkesel olarak değil zamanlama yönünden eleştirmiş, devletin serbest ticareti benimsediğinde sanayinin çöküşte olduğunu Avrupa ürünleri maliyetinin düşük olmas1 nedeniyle var olan sanayinin de ortadan kalktığını vurgulamıştır (Namık Kemal, 1868c: 1-2). Anlaşmadan dış ticaret açısından istifade edilemediği gibi iç ticaretin de yabancı tüccarlara kaptırıldığını ifade etmiştir (İnsel, 2005: 45-46). Ayrıca Namık Kemal, bu asırda ülkenin iktisadi zenginliğinin ticarette emniyet ve itibarla sağlandığını belirtmiştir (Namık Kemal 1866-c: 1-2). Ziya Paşa da Hürriyet gazetesi sütunlarında kapitülasyon, imtiyaz ve mülk edinme hakkı gibi nedenlerle ülkede yabancıların ekonomi ve mali gücü elinde tuttuğunu dile getirmiştir. Halkın geleneksel giyimlerini değiştirmesiyle yerli sanayinin gerilediğini ve halkın üretimde verimli işlerden çok verimli olmayanlar işlerle iştigal ettiklerini belirtmiştir (Karpat, 2006: 40). Devletin 1838 ticaret anlaşmasından bu yana izlediği yanlış iktisadi politikalar sonucu ülkeye Avrupa ürünlerini dolduğunu ifade etmiştir. Anlaşma sonucu Avrupa'nın kalitesiz ürünlerin ülkeye yığıldığını ve yerli sanayinin çökmesini hızlandırdığını belirtmiştir (Önsoy, 1988: 30-31). Yabancı tüccarlara verilen imtiyazların Türk tüccarlarını ortadan kalkmasına neden olduğunu ifade etmiştir (Mardin, 2002: 391-392).

1868 senesinde yayımlanan Terakki gazetesi Osmanlı'nın ticarette geri kalmasının sebebi olarak diş ülkelerde ticaret evlerinin açılmaması ve ticaret şirketlerinin oluşturulmamasını göstermiş, devlet desteğiyle tüccarların bir an önce ticari faaliyetlere girişmesini istemiştir (Terakki, 1869e: 2). Ticaret için şirketleşmenin gerekli olduğunu vurgulamış, bir ülkenin ticarette kalıcı olması ve ilerlemesinin tek sebebinin şirket kurarak ticaretin yürütülmesini göstermiştir (Terakki, 1869f: 2-3). Ticaretin gelişmesi için posta, telgraf, demiryolu, karayolu, şoseler ile birlikte poliçe ve kambiyo usulünün intizamını, geliştirilmesini ve gerekli eksikliklerin giderilmesini istemiştir (Terakki, 1869g: 3-4). Bir devletin gelişmişliğinin ihracatın ithalata göre çok olması ile belirleneceği ve Osmanlı'nın buna önem vermesini istemiş, bir ülkenin ihracatı ne kadarsa ise ithalatının da o kadar olması gerektiğini belirtmiş̦tir (Terakki, 1869h: 3-4). Ülkede serbest ticarete engel olan yed-i vahit ve esnaf usulünün kaldırılmasını istemiştir (Terakki, 1869i: 2). Ticari kurumun şeffaflığının sağlanması gerektiğini belirtmiş ve bu doğrultuda muhasebe işlemlerinin gerçekleştirilmesinin öneminden bahsetmiştir (Terakki, 1869a: 6).

Ulum 'da Ali Suavi, Müslüman Osmanlı vatandaşlarının ticarete ait bir bilgi ve rağbeti olmadığını, gayrimüslimlerin ise ticarete rağbet ettiğini belirtmiştir. Hristiyanların ellerine geçen parayı ticarette kullandığını, Müslümanların ise servetlerini araziye yatırıp ziraatta kullandığını ifade etmiş, az sermaye ile çok kar edinmek tedbirin ziraatta olmayıp ticarette olduğundan Hristiyanların servet kazandıklarını vurgulamıştır (Ali Suavi, 1870: 735-743).

Kemal, İbret gazetesinde ekonomik çöküşün sebebini 1838 ticaret anlaşmasını göstermiş, yabancıların ticaret kanalıyla ülkeyi sömürdüklerini dile getirmiştir. Yabancıların ekonomide güçlü olmasının sebepleri olarak 1838 ticaret anlaşması, yabancılara verilen imtiyazları, iç gümrükleri, yerli bankaların olmayışını, halkın üretici gibi işlerden uzak duruşu ve ulaşımının yetersizliğini göstermiştir (Çavdar, 2003: 23). Reşit Paşa'nın Avrupalılara Osmanlı Devleti’nde ticarette serbestlik iznini verdiğini, bu serbestliğin kötü durumda olan yerli Osmanlı ticaretini ve sanayisini harap ettiğini vurgulamıştır. İç tüketimi sağlayacak üretimi gerçekleştirememesi nedeniyle Osmanlı'da korumacılık sistemini uygulanmasıyla bir netice alınamayacağını vurgulamıştır. Ticaretin geri kalmasının nedeni olarak Osmanlı'nın uyguladığı iç gümrükleri görmüş ve bunun kaldırılmasını istemiştir (Namık Kemal, 1872b: 1-2). İbret'te imzasız yayımlanan bir yazıda Osmanlı'nın ticarete rağbet etmediği anlatılmış ve yabancıların bu işi yürütmesi eleştirilmiştir. Ülke tüccarların dış ticaretle ilgilenmedikleri sadece iç ticaretle meşgul oldukları belirtilmiş bunun ise ülke açısından zararlı olduğu ve ülke sermayesinin harice aktığ 1 vurgulanmıştır (İbret, 1872: 1). 


\subsection{Mali Bürokrasi ve Politikalar}

Osmanlı Devleti'nin iktisadi olarak geri kalmasının nedeni olarak mali bürokratların iktisadi politikalarındaki dirayetsizliği dönemin gazetelerinde sürekli değinilen konulardan biri olmuştur. Mali bürokratların uyguladığı yanlış iktisadi politikalar sonucu ülkenin bu hale geldiği gazete yazılarında sürekli vurgulanmıştır. Bu konuda en sert eleştiri Ali Suavi Muhbir ve Ulum Gazetesi'nde dile getirmiştir. Ali Suavi Muhbir'de bürokrasinin mali politikaları halktan gizleyerek yürüttüğünü belirtmiş ve devletin bu konuda şeffaf olmamasını eleştirmiştir (Ali Suavi, 1868e: 2-3). Bürokrasinin Avrupa ülkelerinden aldığı borçların çoğunu kendi zimmetine geçirip Taksim, Beyoğlu ve İstinye'de konak ve yalı yaparak israf ettiği dile getirmiştir (Muhbir, 1867a: 4). Bürokratların lüks ve sefahat halinde yaşadığını, bürokratların çoğunun devlet paralarını zimmetine geçirdiğini ve bunların sahip olduğu paraların devletin borcunu ödeyeceğinden fazla olduğunu ifade etmiştir. Devletin bu tip bürokratların suiistimaline son vermesini, onlardan yaptığı israfın parasını tahsil etmesini ve görevlerinden alınmasını istemiştir (Muhbir, 1867b: 2). Mali bürokratlara eleştirmesine karşın devletin başarılı mali bürokratlarını ise övmüştür (Muhbir, 1867d: 1-2). Suavi, Ulum'da, bir ülkede güvenliğin sağlandığı takdirde o ülkede alım-satımın çoğalacağını, sanayi gelirlerinin artacağını, dış ve iç ticaretin terakki edeceğini ve genel harcamaların çoğalacağını bu nedenle de mali gelirlerinin artacağını vurgulamıştır (Ali Suavi, 1870: 772-777). Devletin kah iane kah sikke tağşişi kah kağıt paranın ihraç edilmesi gibi yöntemlerle gelirlerini toplamasına karşın devlet gelirlerinin azaldığını ifade etmiştir (Ali Suavi, 1870: 1049-1055). Devletin yakın yerleri, yani İstanbul'un vergiden muaf tutulmasını eleştirmiş (Muhbir, 1867c: 4) ve birçok kişiden alacağı olmasına rağmen bunları alamadığını belirtmiştir (Ali Suavi, 1867b: 3).

Osmanlı mali bürokratlarını eleştiren diğer bir yazar Namık Kemal olmuştur. Namık Kemal bir yazısında ekonomi işlerinin yürütülmesi için mali teşkilatın düzenli bir nizama ve dirayetli memurlara ihtiyacı olduğunu ve maliyenin 1slahı için bu iki konunun önemsenmesini istemiştir. Halka ekonomi ve maliye öğretecek bir okulun olmadığını, mali memurların liyakate göre seçilmediğini, mali politikaları icra eden memurların ancak bireysel zekâ ve yeteneğe göre iş yaptığını ifade etmiş̧ir (Namık Kemal 1866b: 1-2). Kemal, sarayın gereksiz harcamalarına da değinmiş ve Babıâli'nin yanlış iktisadi politikaları sonucu israfın arttığını belirtmiştir. Osmanlı'nın üçüncü sınıf bir devlet olmasına rağmen israfin Fransa'dan fazla olmasını eleştirmiştir (Namık Kemal, 1868a: 1-3). Ziya Paşa, Hürriyet'teki yazılarında bürokratların maliyeyi yönetmede beceriksizlik gösterdiğini, borçlanmanın ekonomiyi mahvettiğini, tüccarların devlet memurluklarına rağbet etmesiyle maliyeye yüklenen yükün arttığını belirtmiş̧ir. Mali bürokratların bilgisizliği ve yeteneksizliğinin ekonomin gerilemesinin en önemli nedeni olarak göstermiştir (Mardin, 2002: 391-392).

Kemal, Ibret gazetesinde halkın sorunlarına da değinmiş ve Babıali’nin iktisadi politikalarını özellikle de vergi politikasını sertçe tenkit etmiştir. Yazılarla, devletin farklı isimler altında topladığı vergiler hakkında okurları bilgilendirmiş ve vergi alırken belirli kurallara uyması gerektiği ve keyfi bir şekilde vergi toplamasının hakkı olmadığını ifade etmiştir (Kızılca, 2012: 347). İstanbul'da vergi alınmamasını eleştirmiş ve İstanbul'dan düzenli bir vergi alındığında hazinenin yarar göreceğini belirtmiştir (Namık Kemal, 1872d: 1).

1860 yıllarında ülkede kâğıt para basılması nedeniyle Мecmua-i Fünun'da bu konu hakkında yazılar yayımlanmıştır. Münif Efendi, fazla miktarda basılan kâğıt paraların halk üzerinde olumsuz etkiler doğurduğunu ve halkın hoşnutsuz olduğunu ifade etmiştir (Münif Paşa, 1866a: 41-46). Terakki gazetesi ise halkın servet imkânının artmasının devlete daha fazla gelir imkânı doğuracağını belirtmiş, fazla vergi alındığında halkta servetin birikmeyeceğini ve bu nedenle hazine gelirlerinde bir azalma görüleceğini belirtmiştir (Terakki, 18691: 1-2). Şark gazetesi ülkenin bütçe dengesi oluşturmak için harcamaların kısılması ve mevcut gelirlerin artırılması yöntemiyle başarı elde edilemeyeceğini belirtmiştir. Ülke gelirlerinin ancak devletin servet kaynaklarından istifade ederek olacağını ifade etmiş, bu doğrultuda devletin tarım ve 
sanayide üretim gerçekleştirilmesi ve ülkenin maden kaynakların istifade edilmesi istenmiştir. Devlet maliyesinin ancak bu şekilde düzlüğe çıkacağı ifade edilmiştir (Şark, 1873d: 1).

1875 senesinde yayımlan Vakit gazetesinde ekonomi ile alakalı yazılarla halkın iktisat sorunlarına olan ilgisi canlı tutulmak istenmiş, devletin ekonomisini geliştirmek amacıyla maliyenin 1slah edilmesi gerektiği vurgulanmış, harcamalarda tasarrufa gidilmesi gerektiği aktarılmıştır. Servetin artırılması için harcamaların azaltılması gerektiği ve borçlanmalarla elde edilen sermayeyi üretim getirecek yatırımlardan ziyade tüketim eksenli lüks bayındırlık faaliyetlerinde harcandığ 1 belirtilmiş ve bunun da ülke ekonomisini zor durumda biraktığı ve devlet gelirlerinin borçların faizlerine ödenmesi nedeniyle bunalımın daha büyüdüğü ifade edilmiştir. Ülkede bürokratların israf içerisinde olduğu, vergilerin fazla olduğu ve indirilmesi gerektiği belirtilmiş, devletin, ziraat ve ticaretini geliştirmesi için halka destekte bulunulması istenmiştir (Yerlikaya, 1996: 79-80).

\subsection{Borçlanma}

Osmanlı Devleti'nin 1854 senesinde gerçekleştirdiği dış borçlanmayla birlikte devletin bütçe açıklarını gidermek için borçlanma politikası çözüm olarak görülmüş ve ilk borçlanmadan sonra devlet birçok diş borçlanma gerçekleştirmiştir (Kıray, 1993: 205-221). Devletin yapmış olduğu borçlanma politikaları dönemin basınında değinilen önemli iktisadi konulardan olmuştur. Namık Kemal, Şinasi'nin yurt dışına kaçması sonrası Tasvir-i Efkar'ın yönetimini üstlenmiş ve gazetede devletin ekonomi politikalarını eleştirmiştir. Borçlanmanın geçici yarar getirdiğini belirtmiş, Osmanlı iç borçlanması eshamın dış borçlanmaya göre daha faydalı olduğunu vurgulamıştır (Namık Kemal, 1866a: 1-3).

Borçlanma politikalarına en sert tepki Ali Suavi’nin yazılarında görülmüştür. Ali Suavi, Muhbir'de halkın mali politikalardan haberdar olmasını istemiş, maliyenin içinde bulunduğu zor duruma rağmen bürokratların savurgan harcamalarda bulunduğunu belirtmiştir. Devletin zor durumda iken dış borç alabileceğini ancak günlük ihtiyaçlarını yürütmek amacıyla yaptığ 1 borçlanmanın uygunsuz olduğunu belirtmiştir. Avrupa güçlerinin Girit meselesini çıkmaza sürükleyerek Osmanlı'nın daha fazla borçlanmasını istediklerini ifade etmiştir (Çelik, 1994: 675). Devletin dış borç yaptığını, bu miktarın israf edilerek çarçur edildiğini ve borç faizlerinin diğer bir borçla ödendiğini belirtmiştir (Ali Suavi, 1870: 1055-1058). Suavi, Muhbir'in çeşitli sayılarında yayımladığı ilanlarla, Babıâli'nin yaptı̆̆ borçlanmanın kabul edilmeyeceğini ümmet namına ilan etmiş ve hükümete protestolar çekerek bu borçların ödenmeyeceğini bildirmiştir (Ali Suavi, 1868abcd: 4;1;1;1). Savaş ve yatırım harcamaları hariç borca girişilmemesini, yapılacak borçlanmanın zararlı şartları ve yüksek faizli olmamasına özen gösterilmesinin gerektiğini belirtmiştir (Ali Suavi, 1867a: 1-2).

Namık Kemal Hürriyet gazetesinde mali krizin çözümünde borçlanmanın bir yöntem olarak kullanılmasını da eleştirmiş ve 1838 ticaret antlaşmasının yerli sanayisinin çökmesine sebep verdiğini belirtmiştir. Borçlanmaya vatanın büyük bir felaketten kurtarılma gibi olaylar dışında başvurulmamasını vurgulamış ancak her mali kriz de Babıâli'nin borçlanmaya başvurmasını eleştirmiştir (Namık Kemal, 1868b: 1-2). Hürriyet gazetesinde borç anlaşmalarına karşı çıkan diğer aydın Ziya Paşa'dır. Ziya Paşa, borçlanmaların Babıâli'nin işine gelmesine karşın Osmanlı halkının bu işe kesinlikle karşı çıktığını belirtmiştir (Ziya Paşa, 1868: 5). Ayrıca gazetede Osmanlı vatandaşlarından gelen bir protestoname yayımlanmış ve bu protestoname ile yapılacak borç anlaşmasına karşı çıkılmıştır (Kanizade Rlfat, 1868: 1-2).

Takvim-i Ticaret, maliyenin ilerlemesine engel olan şeyin devlet borçları olduğunu ve borçların hazinede büyük bir harcama olarak gözüktüğünü belirtmiştir. Hazinenin üçte birinden çoğu hatta yarısına yakın bir miktarın borçların faizine gösterildiğini ve bu nedenle hazinenin daha fazla borçlanmaya müsaade etmediğini vurgulamıştır (Takvim-i Ticaret, 1867c: 1). Şark gazetesi, Osmanlı maliyesinin borçlanmayı artık kaldıramayacak durumda olduğundan borçlanma politikasının artık mümkün olmadığını ve devlet gelirlerin önemli bir kısmının ipotek altına alındığı için maliyenin yeni borçlanmaları karşılayacak gücünün olmadığını belirtmiştir. 
Galata bankerlerinin zor durumda olduğundan devlet hazinesine herhangi bir borç veremeyeceklerini dile getirmiştir (Şark, 1874b: 1). Reşad Bey de Ibret gazetesinde devletin istikrazı çoğaldıkça verginin miktarı da artacağını toplumda hukuksuzluk ve asayişsizliğin doğacağını belirtmiştir (Reşad, 1872b: 1).

Devletin yapmış olduğu borçlanma politikasını doğrudan eleştirmeyen Terakki gazetesi devletlerin yapmış olduğu borç antlaşmaların devletlere karşılıklı olarak fayda sağladığına değindikten sonra bir ülkenin dış borçlanmadan çok iç borçlanma yapmasını istemiştir (Terakki 1869k: 1-2). Borçlanmanın ne niyetle alınmışsa oraya harcanmasını dile getirmiş, eğer yatırım için borçlanma yapılırsa uzun vadede faydanın görüleceğini vurgulamıştır (Terakki, 1869b: 2).

\subsection{Bankacılık}

Osmanlı Devleti'nde Mithat Paşa'nın 1863 senesinde Tuna vilayetinde kurduğu menafi sandıkları ülke ekonomisine olan faydaları dönemin basınında değinilen konulardan biri olmuştur (Yazan, 2017: 222). Местиа-i Fünun'da ülkede yaşanan sermaye sorununa çözüm olmak amacıyla tesis edilen menafi sandıkları hakkında yazılar yayımlamıştır. Kadri Bey, menafi sandıkların para yatıranlara faiz vererek sermayenin artırılmasını temin etmesi ve küçük sermayelerin biriktirerek bu sermaye ile tüccar ve sanat erbabının istifade etmesini sağlamasıyla ülke ekonomisinin gelişmesine katkı sağladığını belirtmiştir. Ülkede halkın para biriktireceği bu tarz sandıkların olmaması yüzünden ülke servetinden istifade edilemediğini ve bu sandıkların tesisinin yaygınlaşmasıyla ticari ve sanayinin gelişeceğini ifade etmiştir (Kadri, 1864: 389-396). Münif Efendi sandıklarının sermayesinin çoğalmasıyla arzu olunacak her türlü sanayi teşebbüsüne girişileceğini vurgulamıştır (Münif Efendi, 1866b: 96-102). Takvim-i Ticaret gazetesi de menafi sandıklarını ülkede sermaye sorununa çözüm getirecek bir kurum olarak görmüştür. Menafi sandıkların halk arasında para biriktirme duygusunu teşvik ettiğini ve halkın sandığa parasını yatırmasıyla zor günlerinde sefalete düşmesini engelleyeceğini ifade etmiştir. Menafi sandığında biriken sermayeyle demiryolu ve nafia girişimlerin hızlı ve kolay yapılacağını belirtmiştir. Ülkede halkın dişinden tırnağından artırdığı akçeyi yatırmak için menafi sandıkları gibi emin yerler olmadığından bu gibi sermayeleri yastık altında veya toprakta defnederek sakladıklarını ve bu sermayenin de ülkenin hayrına istifade edilmediğini dile getirmiştir (Takvimi Ticaret, 1866g: 4).

Faiz politikalarının İslam dinine aykıı olmadığına Ali Suavi değinerek ülkede bankacılık işlemlerine rağbet olunmasına çalışmıştır. Bu doğrultuda Suavi, Ulum'da faiz ve ribanın aynı şey olmadığını, farklı anlamları olduğunu ve karıştırılmaması gerektiğini açıklamıştır. Kuran'da yasaklanan şeyin aslında riba olduğunu belirtmiş, ticari işlemlerde belli bir faiz oranın olağan olduğunu ve faizin ticaretin tabiatından kaynaklandığını ifade etmiştir (Ali Suavi, 1869: 340-341). Ülkede faizden ziyade ribanın yasak edilmesi gerektiğini dile getirmiş, bu doğrultuda tüm ülkelerde faiz sisteminin uygulandığını ve faizin Fransa'da \%5-6 ve Osmanlı'da ise \%12,5 ile sınırlandırıldığını belirtmiştir (Ülken, 2005: 87). Suavi ayrıca Ulum'da, harcamalara dikkat ederek tasarruf yapılmasını ve israf edilmemesini istemiştir. Ülkede biriken milyon liraların heba edildiğini belirtmiş bunun sebebinin ise ülkede tasarrufun olmamasından kaynaklanmadığını bilakis İslam dininin tasarruf üzerine şekillendiğini Kuran'ın birçok ayette israfı eleştirdiğini belirtmiştir. Halktan alınan aşar, iltizam ve vergi gibi ekonomi politikaların tasarrufu engellediğini ifade etmiştir (Ali Suavi, 1869: 607-612).

1863 senesinde yabancı ortaklık girişimi kurulan Osmanlı Bankası kuruluşu dönemin gazetelerinde değinilmiştir. Местиа-ı Fünun'da yayımlanan bir yazıda Kadri Bey, hükümetin izniyle İngiliz ve Fransız sermayelerinden oluşan bir kumpanya tarafindan devletin resmi bankası Bank-1 Osmanî’nin kurulduğunu belirtmiştir. Bankanın kurulmasıyla ülkede ticari işlemlerin kolaylaşacağını ve ülke üretimini artırmaya yardımcı olacağını ifade etmiştir (Kadri, 1863c: 495502). Diğer bir yazıda ise Kadri Bey, bankaların ortaya çıkış sürecini Avrupa'da ilk bankaların kuruluşunu sırası ile anlatmış ve ilk bankalar hakkında bilgi vermiştir (Kadri, 1863d-e: 10-17:5261). Mir'at gazetesi de bankaların emniyetli olduğunu bankaların büyük ve küçük sermayelerin 
muamele icrasını yönettiğini ve bankalar sayesinde halkın biriktirdiği paralardan ülkenin kazanç sağladığını ve ticari işlemlerin kolaylaştığını belirtmiştir (Mir'at, 1863: 37-38). Tercüman-ı Ahval'de Şerif Efendi bankaların Avrupa'nın birçok başkentlerinde görüldüğünü ve Osmanlı'da da kurulduğunu ve faaliyetlerini geliştirdiğini belirtmiş ve bankaların işleyişi hakkında okurlara bilgi vermiştir (Şerif Efendi, 1861e-f, 2-3, 2-3).

\subsection{0. Şirketleşme ve Çalışma}

Ülkenin iktisadi kalkınmasının gerçekleşmesinin ülkede özel teşebbüs gerektiren işlerde sa'y u amel olmasıyla gerçekleşeceği ve kurulacak iktisadi işletmelerinin bireysel olarak değil halkın bir araya gelip şirketler kurarak gerçekleşmesi gerektiği gazetelerin vurguladığ konulardan biri olmuştur. Мeстиa-ı Fünun'da dönemin önemli kavramı olan "Lüzum-ı Sa' y u Amel" hakkında Şerif Efendi ve Macid imzalı iki yazı çıkmıştır. Şerif Efendi, makalede üretimde gerekli olan ihtiyacın çalışma olduğunu vurgulamış, çalışmaksızın ülkelerin refaha erișemeyeceğini ayrıca modern bilgi ve tekniklerini kullanarak üretimi gerçekleştirmesini istemiştir (Karaoğlu, 2013: 287). İnsan tasarrufunda olan tüm şeylerin sa'y u amelle üretildiğini ve paranın say u amel sonucu elde edildiğini ve bunun bitmesi halinde tekrardan sa'y u amele müracaat edildiğini ifade etmiştir (Şerif Efendi 1863: 333-337). Macid Bey ise, insanın zorunlu maddi ve manevi ihtiyaçlarını tedarik etmek için sa'y u gayrete önem verilmesi gerektiğini ifade etmiş̧ir. Çalışmanın insanın en temel vazifelerden biri olduğunu ve bunun için gerekli çabanın gösterilmesini istemiştir (Macid 1866: 201-206). Münif Efendi ise bu konuya "Tahsil-i Servet" makalesiyle değinmiştir. Münif Efendi, insanoğlunun hammaddeleri sa'y u amelle işleterek istifade edecek bir duruma getirdiğini bunun da eğitimle bilgi donanımı artırarak elde edeceğini belirtmiştir. Bir ülkede halkın bilgi seviyesi ne kadar yüksekse sanayinin o derece terakki edeceğini vurgulamıştır (Münif Efendi 1883: 15-22).

Şirketleşme konusuna en fazla önem veren gazete Hadika gazetesidir. Gazete tüccarların yalnız başına ticari teşebbüslerde bulunmasıyla ticaretin terakki edemeyeceğini şirketler teşkil edilmesiyle ülke servetinin artacağını ifade etmiş̦tir (Hadika, 1870: 215). Hadika sanayi üretiminin ancak şirketler tarafından gerçekleştireceğini ve şirketler sayesinde fabrika gibi sanayi tesisleri kurulduğunda sanayi ürünlerin artık hariçten alınmayacağını belirtmiştir (Hadika, 1870: 246-247). Şirketlerin kurulmasının ülke servetinin artmasını sağlayacağı gibi halkı zenginleştireceğini de belirtmiş, Müslümanların şirketlere lakayt kalmasını eleştirmiştir (Hadika, 1870: 254-255). Şirketler tarafından kurulan fabrikalarda sanayi üretimi gerçekleştirildiğinde yabancı mallara olan rağbetin azalacağını ifade etmiştir. Ayrıca halkın moda tarzı ürünlere aldanarak gerçekleştirdiği Batı tarzı tüketim anlayışının ülkeyi kısa zamanda fakirleştirdiğini belirtmiştir (Hadika 1870:263-264). Halkın \%10'un yerli fes kalanın ise Fransız fesini kullandığını belirtmiş ve bunun nedenini ise üretilen feslerin tüketimi karşılayamamasını göstermiştir. Şirket tesis ederek dâhili üretim çeşitlendirilip ihtiyaç oranında üretim gerçekleştirildiği zaman yabancı mallarına olan rağbetin yerli mallarına döneceğini vurgulamıştır (Hadika, 1870: 271). Hadika, Trabzon bölgesinde tüccar tarafindan kolektif tarzında bir şirketin kurulduğunu duyurmuş, Sürmene bölgesinde kaliteli iplik üretildiğini iplik ticaretin Trabzon, İstanbul ve Rumeli bölgelerinde rağbet gördüğünü belirtmiş̧tir (Hadika, 1870: 272;276). Ayrıca ülkede kurulacak deniz nakliyat şirketleri sayesinde tarımsal ürünlerin şehirlere naklinin kolaylaşacağını belirtmiş ve bu tarz şirketlerle pek çok kişiye istihdam kapısının aşılacağını dile getirmiştir (Hadika, 1870: 287). Halkın şirketler kurması için girişimde bulunmasından sonra devletin bu tarz girişimlere destek olacağını hatta birçok imtiyaz tanıdığını belirtmiştir (Hadika, 1870:295). Şirketlerin az miktarda kurulduğunu ve kurulanlara ise halkın ilgi göstermediğini ifade etmiştir. Bu tarz şirketlerin iktisadi gelişim açısından önemli olduğunu ve bu nedenle halkın bu tarz şirketlerin kurulmasına rağbet edilmesine çalışılmasını istemiştir (Hadika, 1870: 341-342).

Ali Suavi, Muhbir'de Osmanlı'da faaliyet gösteren kumpanyaları Osmanlıların işletmesini istemiş, Osmanlıların kuracakları şirket ve kumpanyaların devletten bağımsız olması gerektiğini vurgulamıştır (Muhbir, 1867b: 3). Terakki gazetesinde Hayrettin Bey Osmanlı'nın harap olmasının en büyük sebebi olarak şahsi menfaatlerin gözetilerek bir işi elbirliğiyle 
yapılmamasını göstermiştir. Halk, kendi kişisel çabasıyla bir işi yürütmekten ziyade devlet kapısında memur olmak arzusu taşıdığını ve halkın bu durumdan kurtulması gerektiğini vurgulamıştır (Hayrettin 1868: 4-5). Мecmua-ı Fünun'da Vahan Efendi, "Fevaid-i Şirket" başlıklı yazıda şirketlerin vatandaşın yaşam standardını yükselttiğini ve bunun yaygınlaşmasında önemli bir katkı sağladığını ifade etmiştir (Nalcıoğlu, 2013. 381-382). Halkın kanaatkâr olması ve fazla kazanç getirecek meşgalelerde bulunmaması gibi ahlaki düşüncesi nedeniyle ülkede halkın ticarete rağbet etmediğini ve bu nedenle ticaretin gelişmediğini ifade etmiştir. Ticaretin gelişmemesi nedeniyle şirketlerin de görülmediğini belirtmiştir. Ortak iş yapmanın her işte başarılı sonuçlar verdiğini, bu doğrultuda halkın sermayelerini birleştirip şirketler kurulmasını istemiştir (Vahan Efendi, 1863: 343-353).

Mir'at gazetesi ise ülkede üretilen ürünlerin kaliteli olmasına karşın pahalı üretildiğini bunların ucuz üretilmesinin çarelerine bakılmasını ifade etmiştir (Mir'at, 1863: 20-21). Küçük sermayeyle kurulan şirketlerin birleşerek büyük şirketler kurup rakipleriyle daha iyi rekabet edeceklerini ifade etmiştir (Mir'at, 1863: 36). Takvim-i Ticaret, şirketlerin her ülkenin iktisadi hayatında önemli bir güç olduğu belirtmiş ve bir ülkenin gerek imar ve refahı gerek servetin artmasında şirketlerin büyük faydaları olduğu ifade etmiştir (Takvim-i Ticaret 1866c: 1). Şark gazetesi ise, iktisadi üretiminin gerçekleşmesi için öncelikle hukuk düzeni, ülkede asayiş ve intizamın sağlanmasını istemiştir. Ziraat, sanayi ve ticari teşebbüslerin özel şahıslar tarafından yürütülmesini istemiş ve devletin bu sektörlerde girişimde bulunmasına halkın özel girişim teşebbüslerini azaltacağını ve bu gibi teşebbüslerin devlet tarafından temin edilmesi duygusunun kalıcı bir hale gelmesine neden olacağı ifade etmiştir (Şark, 1873a: 1).

\subsection{Sergiler}

1863 senesinde İstanbul'da açılan uluslararası İstanbul sergisi nedeniyle dönemin gazeteleri serginin açılışına özel önem göstermişler ve bu doğrultuda sergilerin iktisada olan faydalarına değinmişlerdir. Şinasi, Tasvir-i Efkar'da 1863 senesinde açılan Sergi-i Umumi-i Osmani dolayısıyla sergi konusuna değinmiştir. Serginin bir ülkenin sahip olduğu sanayiyi göstermesi nedeniyle o ülkenin sanayi tecrübesini gösteren bir kitap olduğunu belirtmiş, serginin ülke sanayisinin 1slahı ve gelişmesine hizmet ettiği gibi üretilen eşyaların eksikliklerinin giderilmesine yardımcı olduğunu belirtmiştir. Sergide sergilenen Tophane fabrika ürünlerinin ve tersane aletlerinin Osmanlı'da takdir edilecek bir sanayi bilgi ve birikimin olduğunu gösterdiğini dile getirmiştir. Sergide ürünlere bakılırsa Osmanlı'nın servet kaynağının tarımsal ürünlerinden oluştuğunu belirtmiş, ülke sanayisini Avrupa kadar ilerletip sanayide istifade etmenin zor olacağını bu nedenle, Osmanlı'nın ziraatta kalkınmasını istemiştir (Şinasi, 1863a: 1-2).

Местиа-ı Fünun, 1863 açılan Sergi-i Umumi Osmani nedeniyle sütunlarında bu konu hakkında birçok yazı kaleme almıştır. Dergide yayımlanan yazıda Kadri Bey, serginin başlıca faydasının ülkede üretilen tüm sanayi ve zirai örneklerinin gösterilmesiyle ürünlerin kıyas edildiğini ve bu doğrultuda ürünlerin geliştirilmesi için fayda sağlandığını belirtmiştir. Ayrıca ziraat ve sanayi şubelerinin durumunu devlete gösterdiğini ve hükümetin de gerekli adımları atmasına yardımcı olduğunu ifade etmiştir (Kadri, 1863a: 337-342). Kadri Bey, diğer bir yazıda serginin ilk defa açılmasına karşın serginin organizasyonun mükemmel olduğunu, Avrupa'da yapılan sergiler derecesinde bir düzenle sürdüğün̈̈ belirtmiştir. $\mathrm{Bu}$ tarz sergilerin fazla açılmasıyla sanayi ve ziraatın gelişmesine olumlu katkı sağlayacağını vurgulamıştır. Sergideki ürünlere bakıldığı zaman sanayinin gelişmemiş olduğunun anlaşıldığını belirtmiş ve bu nedenle ülkede sanayi fennini öğretecek sanayi mekteplerin kurulmasını istemiştir (Kadri, 1863b: 430434).

Refik Bey tarafından yayımlanan Mir'at dergisinde İstanbul'da açılan sergi hakkında birçok yazı yayımlanmıştır. Mir'at sergide gösterilmek amacıyla getirilen ziraat aletlerin işleyişi hakkında bilgi vermiş ve resimlerini gazetede gösterdiği sabanların ülkede yaygınlaşmasını istemiştir (Mir'at, 1863: 28-29;44). Mir'at, Osmanlı sergisinin nizamnamesinin ilgili kısımlarını özet olarak aktarmıştır. Sergide sergilenecek ürünlerin on üç kısma ayrılıp ve ülkede üretilen 
ürünlerin yanında ecnebi ülkelerinden gelen eşyaların da sergileneceği bildirilmiş̧tir (Mir'at, 1863: 14-16).

\subsection{Ulaşım, Madencilik ve Nüfus}

Osmanlı Devleti’nde iktisadi gelişmesinin önündeki en önemli engel ülke ulaşımının gelişmemiş olması dönemin gazetelerinde dillendirilmiştir. Takvim-i Vekayi'de yayımlanan bir yazıda Osmanlı'da ulaşımın gelişmesinin ziraat ve ticaretin gelişmesine katkısı olacağını ifade etmiş ve bu doğrultuda devletin bir meclis kurarak gerekli raporun hazırlanmasına çalıştığını belirtmiştir (Koloğlu, 1981: 152-153). Мecmua-i Fünun dergisinde Mehmed Said yazdığ1 makalede yolların gelişmişliği sayesinde ziraat ve sanayinin gelişeceğini vurgulamıştır (Mehmed Said, 1862a: 186-196). Yolların tarımın genişlemesini temin ederek çiftlik ve hanelerin sayısının artırmasının yanında emlak ve akarın kıymet ve değerini de artırdığını belirtmiştir. Ulaşımın gelişmesinin halkın ticari faaliyetlere rağbeti artırdığını ifade etmiştir (Mehmed Said, 1862b: 232238).

Takvim-i Ticaret ziraatın gelişmesi için ulaşım eksikliğinin bir engel oluşturduğunu belirtmiş̧, devletin her bölgede demiryollarının yapılmasının müşkül olduğunu ve bu nedenle birinci derecede şose yollarının vücuda getirilmesi gerektiğini ifade etmiştir (Takvim-i Ticaret, 1867b: 1). Terakki gazetesi de Osmanlı'nın iç bölgelerini ticaret yollarına bağlayacak yol, demiryolu ve şoselerin olmaması sebebiyle Osmanlı'nın elinde bulunduğu serveti iyi bir şekilde kullanamadığını ifade etmiştir (Terakki, 1869m: 1-2). Ulaşım yetersiz olduğundan verimli Osmanlı arazilerden yeterince istifade edilemediğini ve devletin demiryolu yapımına hız vermesi gerektiğini ifade etmiştir (Terakki, 1870a: 2-3). Ali Suavi ise ülkenin birçok kaynağı işletilmeden Avrupa'ya özenerek yapılan demiryolun fayda getirmeyeceğini ve Avrupa'da ilk önce karayolu ve demiryoluna bağlanan şoselerin yapıldığını sonra demiryolu inşa edildiğini ifade etmiştir (Ali Suavi, 1867c: 4). Hadika ise yolların açılmasıyla ticaretin gelişeceğini belirtmiş ve bu doğrultuda devletin demiryolu politikasını desteklemiş̧ir (Hadika, 1870: 86-87).

Nüfusa iktisadi bir güç açısından değinen yazılarda dönemin gazetelerinde yayımlanmıştır. Namık Kemal, İbret'teki bir yazısında Batı dünyasının nüfus çokluğunda duyduğu endişeye karşılık Osmanlı' da nüfusun azlığından mustarip olduğunu belirtmiştir. Halkın sağlıksız bir beslenme rejimi ile beslendiğini, vücuda zararlı ürünleri yaygın olarak kullandığını söyleyerek bunlardan vazgeçilmesini istemiştir (Namık Kemal, 1872c: 2-3). Terakki gazetesi ise ülkede nüfus sayımı daha önce yapılsaydı Osmanlı'nın nüfus azlığını sebebine daha kolay ulaşılacağını ve buna yönelik tedbirlerin önceden alınabileceğini belirtmiştir (Terakki, 1870d: 12).

Dönemin gazetelerinde madencilik konusuna değinilmiştir. Bu doğrultuda Terakki'de görülen bir yazıda Osmanlı' da maden yataklarının çok olmasına karşılık asrın gerekli teknolojisi ile üretilemediği için verimin elde edilememesi yüzünden madenlerin işletilemediğini belirtmiştir Osmanlı'da metruk halde bulunan maden yatakların işletilmesi için teknolojiye sahip olunmasını ve bu maden yataklarına ulaşacak geniş bir ulaşım şebekesinin yapılmasını istemiştir (Terakki, 1869o: 3). Ali Suavi, Ulum'da Osmanlı'nın maden açısından zengin bir ülke olduğunu ancak bu zenginlikten devletin faydalanamadığını belirtmiştir. Bugünkü gelişmiş Avrupa ülkelerinin maden kaynaklarından istifade ederek bu konuma ulaştığını ifade etmiştir (Ali Suavi, 1869, 3235). Местиа-ı Fünun dergisinde Ethem Pertev ikinci sayıdan itibaren ilm-i maden başlığıyla madenler hakkında bilgi vermiştir. Bu yazılarda madenlerin katı, sıvı ve gaz durumları anlatıldıktan sonra altın, gümüş, kurşun ve diğer madenlerin özellikleri ve dünyadaki dağılımlarına değinmiştir (Ethem Pertev, 1862, 1863; 68-74, 107-113, 208-217, 288-293).

\section{Sonuç}

Bu çalışmada 1831-1876 dönemi Osmanlı basınında görülen iktisadi yazılar incelenmiş ve kamuoyu oluşturan basında devletin uyguladığ ekonomi politikaların nasıl tartışıldığ araştırılmıştır. Bu yıllarda devletin politikalarını eleştiren bir aydın kitlesi oluşmuş ve bu aydınlar 
devletin iktisadi politikalarını eleştirmiş ve devletin iktisat politikalarına yönelik öneriler de getirmiştir. Gazetelerde tartışılan iktisadi politikalar daha çok sanayileşme, ziraatın geliştirilmesi ve borçlanma politikası olmasına karşın basında ülkenin tüm iktisadi politikaları tartışılmıştır. Gazetelerde halkın iktisat bilgi seviyesini artırmak amacıyla bilgilendirici birçok yazı da yayımlanmış, bu yazılarla halka modern iktisat düşüncesi aşılanmış ve modern iktisadi kurumlar öğretilmiştir.

Takvim-i Vekayi, Monoteur Ottoman, Ceride-i Havadis başta olmak üzere ilk dönemki süreli yayımlar daha çok serbest iktisat düşüncesi doğrultusunda yayım yapmış ve ülke kalkınmasında İngiltere'yi örnek göstermiştir. Bu gazeteler ülkenin iktisat politikaların liberal iktisat düşüncesi doğrultusunda olmasına çalışmış ve ülkenin uzmanlaşma açısında ziraat sektöründe kalkınmasını istemiştir. Takvim-i Vekayi ülkenin Tanzimat'ın ilan edilmesiyle görülen özgürleşme neticesinde üretimin arttığını vurgulamış ve ülkede serbestleşme sürecinin ekonomiyi kalkındıracağını ifade etmişstir. Takvim-i Vekayi'nin eki olarak Fransızca yayımlanan Le Moniteur Ottoman'da Batı kamuoyunu yönlendirmek istemiş ve ülkenin serbest ticaret için uygun bir ortam olduğunu belirtmiş ve ülkede ticareti engelleyici kısıtlamaların olmadığını vurgulamıştır. Ceride$i$ Havadis ise, ülkede kalkınma tartışmalarını başlatmıştır. Gazete sütunlarında ise İngiliz sanayisinin çıkarları doğrultusunda ülkenin sanayileşme sürecini eleştirmiş ve ülkenin ziraatta kalkınması için çabalamış ve ziraatın geliştirilmesi doğrultusunda ülke kamuoyunu yönlendirmiştir.

1860 senesi Osmanlı'da birçok gazetenin ardı ardına yayımlanma nedeniyle gerçek anlamda devletten bağımsız bir kamuoyunun oluşmasına neden olmuş ve ilk defa devletin iktisat politikaları eleştirilmeye başlanmıştır. Tasvir-i Efkar ve Muhbir gazeteleri muhalif bir yayım politikası gütmüş ve Babıali'nin borçlanma politikası başta olmak üzere iktisadi politikaları sertçe tenkit etmiştir. 1861 senesinde Churchill'in başlattığı kalkınma tartışmalarına Şerif Efendi de katılmış ve Tercüman-ı Ahval sütunlarında ülke sanayileşmesinin mutlak olarak gerçekleştirilmesini istemiştir. Мeстиа-ı Fünun ve Mir'at dergileri de dönemin önemli bir organizasyonu olan 1863 Sergi-i Umumi Osmani'nin açılışı doğrultusunda sergilerin sanayi ve ziraata olan katkılarına değinmiş ve sergiyi destekleyici ve tanıtıcı birçok yazı yayımlamışlardır. Ayrıca Местиа-i Fünun Batı'da görülen iktisadi kurum ve düşünce hakkında bilgilendirici ve öğretici yazılar yayımlanmıştır. Bu dönemde yayımlanan Ceride-i Ticaret ve Takvim-i Ticaret'te ülke ticaretinin gelişmesi bir yayım politikası gütmüş ve başta tüccarlar olmak üzere halkı ticaret konusunda bilgilendirmeye çalışmıştır. Bu dönemde en etkili yayımlardan biri olan Terakki gazetesi de ülkenin servet kaynaklarından istifade edilmesi için ülkenin ekonomi politikaları konusunda birçok değerlendirmede bulunmuş ve kamuoyunu iktisadi konularda bilgilendirmiştir.

1860'larda basında bir canlanmanın görülmesi ve devletin politikaların kamuoyunda doğrudan tartışılması ve hükümetin sertçe tenkit edilmesi sonucu devlet basını denetim altına almaya başlamıştır. Çıkarılan kanunlarla gazeteler kapatılmış ve gazeteciler ise Anadolu'ya sürgüne yollanmıştır. Devletin basını kısıtlaması sonucu gazeteciler Avrupa'ya kaçmış ve burada devletin iktisadi politikalarını eleştirmeye başlamışlardır. Ali Suavi, Ziya Paşa ve Namık Kemal önderliğinde gazeteciler Yeni Osmanlılar Cemiyeti'ni kurmuşlar cemiyetin yayın organı olarak 1867 senesinde Ali Suavi Muhbir 1868 senesinde ise Ziya Paşa-Namık Kemal yönetiminde Hürriyet gazetesini yayımlamışlardır. Bu iki gazetede İstanbul'daki sert eleştirilerine kaldıkları yerden devam etmiş ve yine başta borçlanma politikası olarak ülkenin iktisadi politikalarını tenkit etmişlerdir. Hürriyet, ülkenin iktisadi gerilemesinin nedenini 1838 ticaret anlaşmasını göstermiş ve sütunlarında anlaşmanın Osmanlı ekonomisine olan zararlarına değinmiştir. Ali Suavi sonraları Yeni Osmanlı Cemiyeti'nden ayrlarak 1870 senesinde Paris'te Ulum gazetesini çıkartmıştır. Bu gazetede devletin iktisadi politikalarına öneriler getirmiş ve halka iktisadi kavramları öğretmeye çalışmıştır.

1870 senelerinde ise en önemli iktisadi yayımlar Hadika ve İbret gazeteleridir. Hadika ülkenin kalkınması için milli iktisat politikaların uygulanmasını istemiş ve ülkede sanayileşmenin görülmesi için şirketleşmenin yaygınlaşmasını istemiştir. Gazete, halkın yerli mallara rağbet 
etmemesi sonucu sanayi üretiminin gerilediğini vurgulamış ülkede yerli malların rağbet edilmesini istemiş ve bunun da ancak "İttihad-ı Efkar-ı Milliye" ruhunun hakim olmasiyla gerçekleşeceğini belirtmiştir. 1871 senesinde yurda dönen Namık Kemal yönetimde çıkan İbret gazetesi de ülkede ekonomi canlanmanın yerli bir iktisat düşüncesiyle olacağını belitmiş ve ülkenin ziraat, sanayi ve ticaret kaynaklarından istifade edilmesini istemiştir. Gazetede devletin vergi politikalarını eleştirilmiş ve devlet gelirlerinin artırılması için çeşitli öneriler getirilmiştir. Bu dönemde çıkan Şark ve Vakit gibi gazeteler de sütunlarında ekonomi yazılarına yer vermiş ve halkın ülke ekonomisi hakkında bilgi sahibi olmasına çalışmışlardır.

\section{Kaynakça}

Ali Suavi, (13 Aralık 1867b). Niçuncu Mektubu, Muhbir, 15, 3.

Ali Suavi, (13 Aralık 1867c). Demiryol, Muhbir, 15, 4.

Ali Suavi, (13 Mayıs 1868a/Mayıs 1868b/3 Haziran 1868c/12 Haziran 1868d). İlan, Muhbir, $34 ; 36 ; 37 ; 38,4 ; 1 ; 1 ; 1$.

Ali Suavi, (16 Şubat 1870). İyi Maliye İyi Politikadan Olur, Ulum, 13, 772-777.

Ali Suavi, (17 Nisan 1870). İtibar-1 Kredi, Ulum, 17, 1049-1058.

Ali Suavi, (2 Ocak 1868e). Niçuncu Mektubu, Muhbir, 18, 2-3.

Ali Suavi, (27 Eylül 1869). İstikraz-1 Bil Rubh, Ulum, 6, 340-341.

Ali Suavi, (28 Kasım 1867a). İstikraz, Muhbir, 14, 1-2.

Ali Suavi, (Aral1k 1869). Tasarruf 2, Ulum, 10, 607-612.

Ali Suavi, (Tarihsiz-1869), Türkiye'de Madenler, Ulum, 1, 32-35

Ali Suavi, (Tarihsiz-1870). Memalik-i Osmaniye'de Ticaret, Ulum, 12, 735-743.

Ali Suavi, (Tarihsiz-1870). Sanayi-i Der Memalik-i Osmaniye, Ulum, 12, 727-732.

Banka ve İmaliyatı ve Muamelatı, (18 Şubat 1870). Hadika, 1, 5-6.

Berkes, N. (1976). 100 Soruda Türkiye İktisat Tarihi, 2, İstanbul: Gerçek Yayınevi.

Birinci Derecede Yapılacak Şey, (16 Haziran 1869c). Terakki, 169, 2.

Birinci Köy ve Ziraat Kalkınma Kongresi Yayını, (1938). Türk Ziraat Tarihine Bir Bakıs, İstanbul: Devlet Basımevi.

Ceride-i Havadis, (11 Nisan 1841). 29, 2

Ceride-i Havadis, (18 Eylül 1840c). 6, 2

Ceride-i Havadis, (25 Aralık 1840e). 19, 2.

Ceride-i Havadis, (25 Eylül 1843). 132, 1.

Ceride-i Havadis, (25 Haziran 1842). 92, 1.

Ceride-i Havadis, (28 Eylül 1840d). 7, 2.

Ceride-i Havadis, (29 Ağustos 1840b). 4, 3.

Ceride-i Havadis, (31 Temmuz 1840a). 1, 2.

Ceride-i Ticaret, (18 Aralık 1857/11 Mart 1858). 1;7, 1;1-3.

Çavdar, T., (2003). Türkiye Ekonomisinin Tarihi 1900-1960, İstanbul: İmge Yayınevi.

Çelik, H., (1994). Ali Suavi ve Dönemi, İstanbul: İletişim Yayınları. 
Erbab-1 İhtikar, (10 Eylül 1869i). Terakki, 230, 2.

Erbab-1 Sanayi ve Ziraate Gayret, (6 Kasım 1870). Hadika, 38, 302.

Erbab-1 Sanayiye Hitab, (14 Mart 1870c). Terakki, 316, 1-2.

Ertuğ, H. R., (1970). Basın ve Yayın Hareketleri Tarihi, İstanbul: Yenilik Basımevi.

Esbab-1 Servet 1-2-3, (Şubat 1863d/(Mart 1863e/Nisan 1863f). Mir'at, 1;2;3, 5-11;20-21;36-38.

Esbab-1 Tedenni Sanat ve Âdem-i İttihad-1 Millet Hakkında İki Kimsenin Muhaveresi 1-2-3-4-5, (18 Mart 1870/26 Mart 1870/2 Nisan 1870/9 Nisan 1870/23 Nisan 1870). Hadika, 5;6;7;8;10, 38-39;46-48;56;63-64:64.

Ethem Pertev, (Ağustos 1862/Eylül 1862/Ekim 1863/Aralık 1863). "Medhal-i İlm-i Jeoloji-İlm-i Maadin,” Местиа-ı Fünun, 2, 3, 17, 19; 68-74, 107-113, 208-217, 288-293)

Hayrettin Paşa'nın Kitabından. (6 Ocak 1869h), Terakki, 52, 3-4.

Hayrettin, (30 Ağustos 1869a). "Hifz-1 Servet Masrafa Dikkatle Olur", Terakki, 222, 1-2.

Hayrettin, (8 Eylül 1869b). "Banka-i Osmani”, Terakki, 228, 1-2.

Hayrettin, (9 Kasım 1868). "Mesail-i Osmaniye”, Terakki, 1, 4-5.

Hulasa-1 Ahvali Maliye ve Mesalih-i Borsa, (17 Haziran 1866e). Takvim-i Ticaret, 20, 4.

Hulasa-1 Ahval-i Muamelatı Ticariye, (9 Haziran 1866h). Takvim-i Ticaret, 19, s.4.

Hulasa-1 Muamelat-1 Borsa ve Mesalih-i Banka, (1 Temmuz 1866f). Takvim-i Ticaret, 22, 4.

Hükümetin Vezaifi, (15 Nisan 1874a). Şark, 116, 1).

Islahatın Cihet-i Maliyesi Hakkında Tetkikat, (13 Aralık 1873a). Şark, Sayı:16, s.1).

Işık M.-Eşitti, Ş., (2014). “Türkiye'de Ekonomi Basının Ortaya Çıkışı, Gelişimi ve Bugünkü Durumu Üzerine Bir İnceleme”, İstanbul Ticaret Üniversitesi Sosyal Bilimler Dergisi, 13( 25). İddihar Sandıklarına Dair Bendin Bakiyesidir, (26 Mart 1866g). Takvim-i Ticaret, 9, 4.

İki Zatın Şirket Teşkili Hakkında Olan Muhaveresi Olup Bir Zat Tarafından Merkezi İdaremize Gönderildiğinden Ayniyla Derc Olunmuştur 1-2-3-4-5-6, (23 Eylül 1870/30 Eylül 1870/7 Ekim 1870/14 Ekim 1870/21 Ekim 1870/28 Ekim 1870). Hadika, 32;33;34;35;36;37, 254255;263-264;271-272:276;287;295.

İlanat, (18 Aral1k 1857/11 Mart 1858). Ceride-i Ticaret, 1;7, 3-4;3-4.

İlm-i Servete Dair Makalemizin Mabadıdır, (2 Aralık 1873c). Şark, 6, 3.

İnceoğlu, F. S., (2005). Tanzimat'ta Bir Düşünür ve Bürokrat: Münif Paşa ve İktisat Tasavvuru, Divan İlmi Araştırmalar Dergisi, 10(19).

İnhisar-1 Duhan, (10 Şubat 1874c). Şark, 64, 1).

İnsel, A., (2005). Türkiye'de Liberal Kavramın Soyçizgisi, Modern Türkiye'de Siyasi Düşünce 7 , Liberalizm, İstanbul: İletişim Yayınları.

İskit, S., (1937). Hususi Ilk Türkçe Gazetemiz ve Agah Efendi, Ankara: Ulus Basımevi.

İstanbul'da Sanayi İnkirazı, (27 Eylül 1869r). Terakki, 242, 1-2.

Kadri, (Haziran 1863d/Temmuz 1863e). "Tarih-i Banka Berveche-i Umumi 1-2”, Мecmua-ı Fünun, 13/14, 10-17;52-61.

Kadri, (Mayıs 1863c). "Bank-1 Osmani”, Местиа-ı Fünun, 12, 495-502. 
Kadri, (Ocak 1863a/Mart 1863b), "Sergi-i Umumi Osmanî”, Местиa-ı Fünun, 8;10, 337$342 ; 430-434$.

Kadri, (Şubat 1864f). “İddihar Sandığg1 1”, Местиа-ı Fünun, 21, 389-396.

Kanizade Rıfat, (22 Kasım 1868). “Babıali’nin Akd Edeceği İstikrazı Ümmeti Osmaniye’nin Kabul Etmeyeceğini Havi İstanbul'dan Yüz İki İmza İle Aldığımız Protestonamedir", Hürriyet, 21, 1-2.

Karaoğlu, Ö., (2013). İktisadi Düşünce Tarihimizde Bir Sayfa: Mecmua-1 Fünun, Akademik Incelemeler Dergisi, 8(1).

Karpat, K., (2006). Osmanlı'da Değişim, Modernleşme ve Uluslaşma, İstanbul: İmge Yayınevi.

Kıray, E. (1993). Osmanlı'da Ekonomik Yapı ve Dış Borçlar, İstanbul, İletişim Yayınları.

Kız Sanayi Mektebi, (18 Mart 1870). Hadika, 5, 37-38.

Kızılca, G. K., (2012). Bu Mülke Gazeteler Fena Hizmet Etmedi Mali Kriz Günlerinde İbret'in Gözünden Babıali, Osmanlı Halkı ve Avrupa Emperyalizmi, Kebikeç, 33.

Koloğlu, O. (1981). Takvim-i Vekayi Türk Basınında 150. Yıl 1831-1981, Ankara: Çağdaş Gazeteciler Derneği Yayınları.

Koloğlu, O. (1988). Osmanlı Devleti'nde Liberal Ekonominin Savunucusu: Blacque Bey (17921836), Tarih ve Toplum, 57.

Koloğlu, O. (1998). Osmanlı Basının Doğuşu ve Blak Bey Ailesi, İstanbul: Müteferrika.

Koloğlu, O. (2000). Avrupa'ya Karşı Osmanlı'yı Müdafaa Eden Avrupalı Blak Bey, Popüler Tarih, 1 .

Koloğlu, O., (2010). Osmanlı Dönemi Basının İçeriği, İstanbul: İstanbul Üniversitesi İletişim Fakültesi Yayınları.

Kumpanyaya Dair, (19 Ağustos 1870). Hadika, 27, 215.

Kurdakul, N., (1997), Tanzimat Dönemi Basınında Sosyo-Ekonomik Fikir Hareketleri, Ankara: Kültür Bakanlığı Yayınları.

Macid, (Ekim 1866). Lüzum-1 Say u Amel, Местиа-ı Fünun, 39, 201-206.

Madenler, (19 Ekim 1869o). Terakki, 257, 3.

Maliye, (19 Mayıs 1874e). Şark, 132, 3.

Mardin, Ş. (1990), Siyasal ve Sosyal Bilimler, İstanbul: İletişim Yayınları.

Mardin, Ş., (2002). Yeni Osmanlı Düşüncesinin Doğuşu, İstanbul: İletişim Yayınları.

Mehmet Mithat, (11 Şubat 1869). Ekonomi Yani İdare-i Umura Dair Yazılan Bendin Mabaadır, 81, 1-3.

Mehmet Said, (Ekim 1862a). Fevaid-i Tarik 1, Местиа-ı Fünun, 5, 186-196.

Mehmet Said, (Kasım 1862b). Fevaid-i Tarik 2, Местиa-ı Fünun, 6, 232-238.

Mehmet Şerif Efendi, (14 Kasım1861c/19 Kasım 1861d). İtibar-1 Umumi Ticarete Dairdir, Tercüman-ı Ahval, 105;107, 2-3;2-3.

Mehmet Şerif Efendi, (19 Ağustos 1861a/22 Ağustos 1861b). Sanayi ve Ziraattan Hangisinin Hakkımızda Hayırlı Olduğuna Dair, Tercüman-ı Ahval, 68/69, 3-4; 2-3.

Mehmet Şerif Efendi, (26 Eylül 1861e/29 Eylül 1861f). Bankaların Enva1 ile Tabiatlarına Dair, Tercüman-ı Ahval, 84; 85, 2-3, 2-3. 
Mehmet Şerif Efendi, (Ocak 1863). Lüzum-1 Say u Amel, Mecmua-ı Fünun, 8, 333-337.

Memalik-i Mahruse'de Tahriri Nüfus, (10 Mart 1870d). Terakki, 313, 1-2.

Muhbir, (1 Kasim 1867a). 12, 4.

Muhbir, (12 Ekim 1867d). 7, 1-2.

Muhbir, (5 Ekim 1867b). 6, 2-3.

Muhbir, (7 Kasim 1867c). 11, 4.

Mukaddime, (18 Aral1k 1857). Ceride-i Ticaret, 1, 1.

Münif Efendi, (Haziran 1866a). Umur-1 Maliyeye Düvel-i Muharebe, Mecmua-ı Fünun, 35, 41 46.

Münif Efendi, (Ocak 1883). Tahsil-i Servet, Местиа-ı Fünun, İkinci Dönem, 1, 15-22.

Münif Efendi, (Temmuz 1866b). Tuna Vilayetinde Menafi-i Umumiye Sandıkları, Mecmua-ı Fünun, 36, 96-102.

Müşkilat-1 Hazire-i Maliye, (20 Şubat 1874b). Şark, 72, 1).

Nalcıŏ̆lu, B. U., (2013). Osmanlı'da Muhalif Basının Doğuşu, İstanbul: Yeditepe Yayınları.

Namık Kemal, (10 Ağustos 1868c). Mülkümüzün Servetine Dair, Hürriyet, 7, 1-2.

Namık Kemal, (17 Ağustos 1868a). Mülkümüzün Servetine Dair Geçen Numaradaki Makaleye Zeyl, Hürriyet, 8, 1-3.

Namık Kemal, (2 Kasım 1872d). Acaba İstanbul'dan Niçin Vergi ve Asker Alınmaz, İbret, 60, 1.

Namık Kemal, (20 Ağustos1866c). Ahval-i Maliyeye Dair Bir Layihadır, Tasvir-i Efkâr, 414, 12.

Namık Kemal, (20 Kasım1872b). Sanayi ve Ticaretimiz, Ibret, 57, 1-2.

Namık Kemal, (21 Aralık 1866a). İstikrazlar Hakkında, Tasvir-i Efkâr, 445, 1-3.

Namık Kemal, (21 Temmuz 1866b). Maliyenin Muamelat-1 Hisabiyyesine Dair Bir Layihadır, Tasvir-i Efkâr, 406, 1-2.

Namık Kemal, (26 Haziran 1872c). Nüfus, İbret, 9, 2-3.

Namık Kemal, (26 Kasım 1872a). Ziraatımız, Ibret, 61, 1-2.

Namık Kemal, (31 Ağustos 1868b). Sekizinci Numaradaki Maliye Bendine Zeyl, Hürriyet, 10, 12.

Nureddin, (21 Haziran 1869a). Ne İçin Bizim Memleketimizde Serveti Umumiye Yani Ticaret ve Medeniyet Bu Kadar Ağır Terakki Ediyor, Terakki, 173(2).

Nureddin, (31 Mayıs 1869b). Esnaflık, Terakki, (158): 4-5.

Önsoy, R., (1988). Tanzimat Dönemi Osmanlı Sanayi ve Sanayileşme Politikası, İstanbul: İş Bankası Kültür Yayınları.

Pamuk Ziraatine Dair Risaledir, (8 Şubat 1866d). Takvim-i Ticaret, 2, 1-4.

Piyasanın Hali, (16 Mart 1874d). Şark, 91, 2.

Piyasanın Hali, (18 Mart 1875). Şark, 375, 1.

Reşad, (26 Haziran 1872a). Fenni Servet, Ibret, (10): 1.

Reşad, (9 Temmuz 1872b). İstikraz, İbret, 19, 1. 
Reşad, (Şubat 1873), Franklin Tarik-i Servet, Cüzdan, (1): 22-28

Sabanlara Dair Malumat, (Mart 1863a). Mir'at, 2, 28-29.

Sanayi, (31 Aralik 1873b). Şark, 31, 1.

Sayar, A. G., (2000). Osmanlı İktisat Düşüncesinin Çağdaşlaşması, İstanbul: Ötüken Yayınları.

Sayar, A. G., (2006). Osmanlı İktisat Düşüncesinin Çağdaşlaşması, İstanbul: Ötüken Yayınları.

Sergi-i Osmanî Nizamnamesinin Hulasa-1 Meali, (Şubat 1863c). Mir'at, 1, 14-16.

Sungu, İ., (1999). Tanzimat ve Yeni Osmanlılar, Tanzimat 2, İstanbul: Milli Eğitim Bakanlığ Yayınlar1.

Şener, A., (1994). Osmanlı Mali Düşüncesinin Çağdaşlaşması, Tanzimat'ın 150. Yıldönümü Uluslararası Sempozyumu 31 Ekim-3 Kasım 1989, Ankara: Türk Tarih Kurumu Basımevi.

Şinasi, (29 Mart 1863a). Osmanlı Sanayi Sergisinin Açılması, Tasvir-i Efkâr, (79): 1-2.

Şinasi, (31 Aralık 1863b). İthalat ve İhracata Ait Gümrük Defterlerinin Tutulması Lüzumu, Tasvir-i Efkâr, 158(1).

Şirket Hakkında Sitayiş ve İhtar, (9 Aralık 1870). Hadika, 43, 341-342.

Takvim-i Ticaret, (1 Aralık 1866b). 44, 1.

Takvim-i Ticaret, (10 Kasim 1866a). 41, 1.

Takvim-i Ticaret, (19 Ocak 1867a). 51, 1.

Takvim-i Ticaret, (2 Haziran 1866c). 18, 1.

Takvim-i Ticaret, (25 Temmuz 1867c). 74, 1.

Takvim-i Ticaret, (26 Ocak 1867b). 52, 1.

Tekdemir, A. (2011), Osmanlı Devleti'nde İlk Ticari Gazete: Ceride-i Havadis, Trakya Üniversitesi Sosyal Bilimler Dergisi, 13(1).

Teksir-i Mahsulat, (2 Aralık 1873d). Şark, 6, 1.

Terakki, (15 Kasım 1869a). 277, 6.

Terakki, (29 Mart 1869b). 113, 2.

Terakki, (9 Haziran 1870a). 377, 2-3.

Terakki-i Sanayi, (31 Ocak 1870b). Terakki, 289, 3-4.

Ticaret, (18 Mart 1874f). Şark, 93, 3.

Ticaret, (2 Ekim 1872). Ibret, 22, 1.

Ticaret, (20 Ekim 1869g). Terakki, 258, 3-4.

Ticaret, (29 Eylül 1869f). Terakki, 243, 2-3.

Ticaret, (29 Nisan 1869e). Terakki, 135, 2.

Usul-i Fen Defteri, (5 Ağustos 1870). Hadika, 25, 195-196.

Ülken H. Z., (2005). Türkiye'de Çağdaş Düşünce Tarihi, İstanbul: Ülken Yayınları.

Vahan Efendi, (Ocak 1863). Fevaid-i Şirket, Местиа-i Fünun, (8): 343-353.

Vergi Maddesi, (1 Nisan 1869l). Terakki, 115, 1-2.

Vergi Maddesi, (19 Nisan 1869m). Terakki, 128, 1-2. 
Vezaif-i Ticariye, (8 Temmuz 1866i). Takvim-i Ticaret, 23, s.1.

Yanardağ, M. F., (2010). Tanzimat Dönemi Fikir Gazeteciliğinin Önemli İsmi Tasvir-i Efkar ve Toplumsal Değişime Katkısı, Tercüman-ı Ahval'in 150. Yılında İstanbul'da Fikir Gazeteciliği Seтроzуити 21-22 Ekim 2010, İstanbul: Emirler Matbaas1.

Yazan, Ö., (2017). Ziraat Bankasının İlk Yirmi Yılına Ait Bazı Kayıtların İncelenmesi, AİBய̈ Sosyal Bilimler Enstitüsü Dergisi, 17(4): 222

Yazıc1, N., (1999). Tanzimat Döneminde Ekonomi Basını: Takvim-i Ticaret, Ankara Üniversitesi Ilahiyat Fakültesi Dergisi, 39(1).

Yerlikaya, İ., (1995). Tercüman-1 Ahval Gazetesi ve Hükümet Destekli Habercilik Anlayışı, Toplumsal Tarih, 21.

Yerlikaya, İ., (1996). 2. Abdülhamid Döneminde Yarı Resmi: Vakit Gazetesi 1875-1884, Kırıkkale.

Zamime, (16 Eylül 1870). Hadika, 31, 246-247

Ziraat Aletlerinin Tarifi, (Nisan 1863b). Mir'at, 3, 44.

Ziraat Mektebi ve Numune Çiftliği, (29 Nisan 1870). Hadika, 11, 86-87.

Ziya Paşa, (29 Kasım 1868). İstikraz-1 Cedid Üzerine Yeni Osmanlılar Cemiyetinin Mütalaatı, Hürriyet, 22(5). 